\title{
CERAMICS, SURVEYS, AND CONNECTIVITY IN WESTERN ANATOLIA: THE MIDDLE AND LATE BRONZE AGE BAKIRÇAY/KAIKOS VALLEY RESTUDIED
}

Peter Pavúk ${ }^{1}$ and Barbara Horejs ${ }^{2}$

Abstract: This paper presents the results of a longterm survey conducted in the Bakırçay/Kaikos Valley and the vicinity of Pergamon, which provides a new primary dataset for the $2^{\text {nd }}$ millennium $B C E$ developments in this area. The archaeological evidence will be outlined in detail for the first time here, embedded in broader cultural and material developments of the Western Anatolian Middle and Late Bronze Ages. The discussion will not be limited to ceramic wares and shapes and the chronological assessment of the finds only, but their distribution within the valley and site hierarchies will be assessed as well. Finally, the significance of the Bakurçay Valley within the broader cultural landscapes of Western Anatolia will be reconsidered.

Keywords: Western Anatolia, Eastern Aegean, Bronze Age, pottery, settlement chambers, survey, prehistoric Pergamon

\section{Setting the stage}

Western Anatolia in the $2^{\text {nd }}$ millennium $\mathrm{BCE}$ is surprisingly hard to grasp, despite being surrounded by relatively well-understood flanking regions. ${ }^{3}$ To the east, on the Central Anatolian plateau, we witness the rise of a sophisticated network of Middle Bronze Age (MBA) Old Assyrian trading posts, which eventually first lead (indirectly) to the formation of the Late Bronze Age (LBA) Hittite kingdom, developing into an empire after c. 1450 $\mathrm{BCE}$. There are remains of large palaces and urban centres with evidence for far reaching long-

ICAR - Institute of Classical Archaeology, Charles University, Prague; email: peter.pavuk@ff.cuni.cz

2 OREA - Institute for Oriental and European Archaeology, Austrian Academy of Sciences Vienna; email: barbara. horejs@oeaw.ac.at

3 The following overview is based on numerous studies of our colleagues, many of which will be quoted repeatedly throughout the paper. Here, however, at least some of the comparatively not so numerous summaries of the developments of the area as a whole should be mentioned: HAwK- distance trade, a multitude of sealing practices, and several archives of written documents in Akkadian, Hittite and Luwian. These archives cover a wide range of topics: royal deeds and annals, cultic texts, diplomatic treaties, letters, and accounting and trade documents, etc. Some of them also mention Western Anatolia, or countries believed to be located here, from as early as the $15^{\text {th }}$ century BCE and with their activities culminating in the $13^{\text {th }}$ century $\mathrm{BCE}$. By that time most of Western Anatolia becomes linked to the Hittite empire through a series of vassal treaties. ${ }^{4}$

To the west, one encounters a slightly more diversified world of the Middle and Late Bronze Age Aegean. Crete, with its Minoan civilisation of the so-called First and Second palaces, was certainly setting the tone in the MBA and early LBA, yielding rich finds of both prestigious and everyday character, as well as the so-far undeciphered Linear A script and abundant sealing bureaucracy. At first, Crete seems to have assumed more of an internal outlook, getting involved mainly in elite communication with the Eastern Mediterranean and in more mundane exchange with the "neighbouring' regions. We do, however, soon witness a spread of a whole package of Cretan material culture traits to the Southern Aegean, such as the socalled conical cups, flat discoid loom-weights, or frescoes. Some even reached the coastal Peloponnese, but their distribution centred mostly on the Cyclades, Dodecanese, and the adjacent Ionian and Carian coast, although additional outliers lie as far north as Samothrace. ${ }^{5}$

INS 1998; Seeher 2005; Niemeier 2007a; Greaves 2010; BRYCE 2011, as well as the relevant recently edited volumes: Coluins et al. (eds.) 2008; Mouton et al. (eds.) 2013; STAMPolidis et al. (eds.) 2015 - many of these tend to be linguistic and historical rather than archaeological in nature.

4 Glatz 2009; Weeden and Ullmann (eds.) 2017; Schachner (ed.) 2017.

5 Broodbank 2004, for a recent overview, see papers in Gorogianni et al. (eds.) 2016. 
While mainland Greece seems to have had a less developed social complexity in the MBA, it still witnessed the emergence of the rich Shaft Grave phenomenon at the MBA/LBA transition in the Argolid and yielded thriving communities in Central Greece and Euboea. The picture starts to change around the middle of the $2^{\text {nd }}$ millennium $\mathrm{BCE}$, when the communities in the Argolid interact more intensively with those on Crete during Late Helladic (LH) IIB, and with palaces having been established on the southern Greek Mainland some time around the LH IIB/LH IIIA1 transition. It is this Palatial Mycenaean period that yielded yet another script, Linear B. Seals continue to be used for administrative purposes, but their meaning seems to have changed from primarily economic to perhaps more of a personal value. From LH IIIA2 onward there is a so-far unpreceded expansion of a certain type of material culture outside of its homeland in the Peloponnese - especially pottery - that came to be labelled as 'Mycenaean'. Not only is the Mycenaean decorated pottery distributed along the Western Anatolian coast in this period, but female textile-workers in the palaces can be identified as coming either directly from Western Anatolia or from the adjacent Eastern Aegean islands. ${ }^{6}$

In the northern Greek Mainland, we witness various forms of Thessalian and Macedonian Bronze Age, its communities intertwined with the developments of the Balkan hinterland, but also selectively adapting and adopting new practices and material culture from the south. These regions remain largely true to their own traditions mainly

6 Maran 2011; Parkinson and Galaty 2007; Eder and Jung 2015; Mountjoy 1998; Nosch and LafFineur (eds.) 2012; ZuRBaCH 2015.

7 Horejs 2007; Pavúk and Horejs 2012; Eder 2009; Bozhinova et al. 2010; Gimatzidis et al. (eds.) 2018.

8 This new approach is represented for example in MAC SWEENEY 2009; 2010; 2011; MOKRIŠOVÁ 2015; VAESSEN 2016; 2017.

9 Our sincere thanks go to the Pergamon excavations/DAI Istanbul (F. Pirson) and the Turkish authorities for permission; funding was provided by ERC Prehistoric Anatolia (263339), FWF Start project (Y 528), the Czech Science Foundation GAČR (Award 17-19746S), and the European Regional Development Fund-Project „Creativity and Adaptability as Conditions of the Success of Europe in an Interrelated World" (No. CZ.02.1.01/0.0/0.0/16_019/00007 34). We further thank the "Prehistoric Pergamon Survey" ERC team (M. Röcklinger, F. Ostmann, Ch. Schwall, J. Traumüller, M. Börner, B. Milić, M. Brandl, L. Schneider, characterised by the use of handmade burnished wares and a lack of script and sealing bureaucracy north of the Mt. Olympus massif. To these characteristic features one can also add a conspicuous absence of communication with Western Anatolia, at least such that would be discernible in the material evidence?

Coming back to Western Anatolia, most studies treat it rather perfunctory, mostly in reference to the above-mentioned polities and their involvement in Western Anatolia, leaving Anatolia somewhat secondary in comparison to the so-called 'high cultures' in the better investigated regions around it. What we need to do, therefore, is to consider Western Anatolia for its own value and understand not only its western coastal stripe, but also the regions further inland. ${ }^{8}$ We are convinced that a substantial understanding of Western Anatolian prehistoric societies also requires an analysis of the various concepts and traditions of archaeological materials at a more regional level. The long-term surveys conducted in the Bakırçay/Kaikos Valley and the vicinity of Pergamon now provide new primary datasets offering the option to conduct this kind of a regional approach, simultaneously embedded in a wider supra-regional context. ${ }^{9}$

\section{Western Anatolia through the lens of surveys}

When we look at the distribution of excavated and published sites in Western Anatolia, one immediately notices a clear pattern: almost $90 \%$ of them are located on the Western Anatolian coast. ${ }^{10}$ The

Th. Urban, M. Bergner, St. Grasböck, D. Wolf, M. Mehofer) and Charles University team (Lucia Šušková and Gerhard Pastirčák). Special thanks go to Eastern Atlas (Berlin) for geophysical surveys, of which the results at Değirmentepe are presented here.

10 Troy (Blegen et al. 1951; 1953; 1958; Korfmann 2006; as well as annual reports in Studia Troica) followed after a large geographical gap by Larisa on Hermos (BoeHlau and Schefold 1942), Panaztepe (Günel 1999a; ErkanalÖKtU 2008; ÇINARDALI-KARAASLAN 2008), Bayraklı (Akurgal 1950; Bayne 2000, 61-80), Liman Tepe (Günel 1999b; Erkanal 2008; Votruba 2015), ÇeşmeBağlararası (ŞAHOĞLu 2007; 2015), Kocabaştepe (AYKuRT 2006), Bademgedığı Tepe (MERIÇ 2003; 2007; MERIÇ and Öz 2015), Ayasuluk (BÜYÜKKOLANCI 2007), Kadıkalesı (Akdeniz 2006; 2007), Miletus (NiEMEIER 2007b, with rich previous bibliography; cf. now RAYMOND et al. 2016), İasos (Momigliano 2009; 2012) and Müsgebi (Boysal 1967), just to name the most well-known. 
few more extensively excavated inland sites include Pergamon (with limited but published excavations), ${ }^{11}$ Sardis (with several deep trenches, largely unpublished) ${ }^{12}$ Gavurkale (with excavation of a central 'megaron', also largely unpublished), ${ }^{13}$ Metropolis and Bademgediği Tepe (with several excavated trenches at both sites and final publication currently in preparation), ${ }^{14}$ Aphrodisias (with several excavated trenches and final publication), ${ }^{15}$ Beycesultan (with extensive old excavations and final publication, as well as new excavations currently underway, published in preliminary reports), ${ }^{16}$ and Çine Tepecik (currently excavated and published in preliminary reports). ${ }^{17}$ Overall, this is not much, actually. Nonetheless, even though these are only a few excavated inland sites, they still offer useful data for the $2^{\text {nd }}$ millennium $\mathrm{BCE}$ and have to be included in our understanding of a local and regional horizon. The importance of the inland sites is proven now even more so with the new excavations at Kaymakçı located on the western slopes of the Marmara Lake basin in the middle Gediz/Hermos River valley, just north of Sardis. So far only preliminary reports have been published, but it is clear that with more data from the site, it will become a reference site of equivalent rank to Troy and Beycesultan. ${ }^{18}$

From a geographical point of view, Western Anatolia is composed of a number of deep and broad valleys, running mostly in east-west direction, separated from each other by long and surprisingly massive chains of hills and mountains, creating a system of distinct settlement chambers. ${ }^{19}$ Whereas in Southwestern Anatolia there is usually at least one well-excavated and published site in each of the chambers, when we move north the situation becomes scarcer. The Gediz Valley

\footnotetext{
Radt 1992; Hertel 2011.

Summarised in SpIer 1983; cf. also Jewell 1974, 109-110.

Meriç 1989; 1990; 1992.

Meriç 2003; 2004; 2007; Meriç and Öz 2015; SChachner and Meriç 2000; Meriç and Mountjoy 2002.

15 Kadish 1969; 1971; Marchese 1976; 1978; JoukowsKy 1986.

16 Lloyd and Mellaart 1969; Lloyd 1972; Mellaart and Murray 1995; DedeoĞlu and Abay 2014.

17 GÜNel 2010; 2015.

18 For preliminary reports, see Roosevelt and LuKe 2010, 7-8, Map. 1, Fig. 11-12; 2011, 56-57, Fig. 1-3; 2013, Roosevelt et al. 2014. For the first extensive English report covering the years 2013 to 2017, see Roosevelt et al. 2018.

19 PAvúK 2015, Fig. 8.

20 SAzCi 2013; 2016; SAzCi and BaŞaran Mutlu 2017; 2018.
}

had until recently no published sites (with the exception of the İzmir area, which is not representative of the whole valley, and the recent excavations at Kaymakçı require more time to be fully published), the Bakırçay Valley is represented only by Pergamon (the challenges of which will be discussed below), and the Troad is represented by Troy (which, unfortunately, is illustrative only of the western Troad). Turkish Thrace has almost no comprehensively researched sites, with the sole exception of the new and exciting excavations at Maydos-Kilisitepe on the Galipoli peninsula. ${ }^{20}$ This is why it is necessary, despite the absence of major excavated sites, to engage again and in more detail with survey material.

Our knowledge of inland Western Anatolia is based mainly on surveys, conducted variously by K. Bittel, C. Blegen, J. Driehaus, J. Mellaart, D. French, M. Özdoğan, R. Meriç, H. Lohmann, E. Akdeniz, R. Aslan, Ch. Roosevelt, Ch. Luke and others. ${ }^{21}$ Just as in the case of excavated sites, not all of them have been fully published. ${ }^{22}$ The real problem, however, remains the absence of excavated and published stratigraphic sequences against which survey material can be compared and thus dated and understood more precisely.

Inching closer to the target of the present paper, the Bakırçay Valley, let us address the more recent survey attempts in its neighbouring regions. In the Troad, the team of M. Korfmann expanded the previous knowledge generated by C. Blegen, A. Akarca, and J. Cook, ${ }^{23}$ and conducted renewed visits to the previously known sites to verify their location and refine their date and interpretation; this effort was coordinated by R. Aslan and G. Bieg. ${ }^{24}$ The combination of survey evidence, new knowledge of the archaeology of Troy itself,

21 Roughly from north to south: ÖZDOĞAN 1991; 1993; CoOK 1973; Akarca 1978; Aslan et al. 2003; Rose et al. 2007; Mellaart 1955; French 1967; 1969; Efe 1994; 1997; Driehaus 1957; Roosevelt and Luke 2017; SChachner and Meriç 2000; Meriç 2007; 28, n. 16; 2009; ÇAymaz 2008; Lohmann 2004; Günel 2003; 2004; 2005; 2006; Mellaart 1954, esp. 179-180; Lloyd and Mellaart 1962, 243-64; 1965, 74-81; Mellaart and Murray 1995, 99-109.

22 A number of interesting observations on various unpublished survey-finds can be still found in BAYNe 2000, passim.

23 Blegen et al. 1950; CoOK 1973; AKarca 1978.

24 Reports on the $2^{\text {nd }}$ millennium sites can be found in AsLAN et al. 2003, and pottery discussed in PAvÚK and SchuberT 2014. 


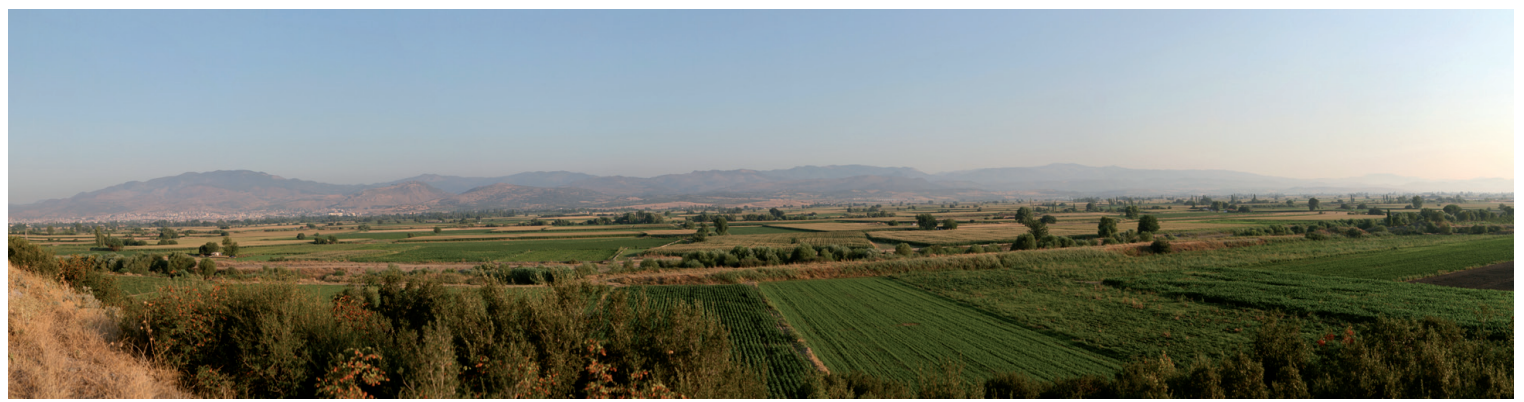

Fig. 1 Panorama view of the Bakırçay Valley from the entrance of the Gümüşova Valley towards the north with modern Bergama and antique Pergamon in the background (Photo by Felix Ostmann/OREA).

as well as the evidence from archaeobotany and archaeozoology led to interesting insights into the $2^{\text {nd }}$ millennium BCE settlement dynamics in the Western Troad (see further discussed below). ${ }^{25}$ To the south, R. Meriç conducted several survey seasons in the Gediz Valley, which have only been published just now. ${ }^{26}$ The first more comprehensive results stem from the recently finished Central Lydia Archaeological Survey (CLAS), covering the region around the Lake Marmara north of Sardis, including the area with Lydian and Persian tumuli called Bin Tepe ('Thousand Mounds' in Turkish). ${ }^{27}$ Though one of the primary motivations of CLAS was to document the Early Iron Age (EIA), the survey discovered a number of Bronze Age sites. Most striking is the suite of six LBA fortified citadels, with the above-mentioned site of Kaymakçı being the largest and with most complex structure. These were accompanied by five unfortified lowland settlements and twenty-three scatters of finds, representing more ephemeral activities. Ceramic fabrics across the various sites were tested chemically, and they reflect all the same chemical profile, which indicated a high degree of centralised production, as was witnessed also around Troy. ${ }^{28}$ What still needs to be ascertained is the interplay between the lowland sites and the citadels.

\section{Surveys in the Bakırçay Valley}

What remains to be discussed is the Bakırçay Valley located in-between, which presents the core of

25 PAvÚK et al. 2014.

26 Meriç 2018; a similarly conducted survey in the Küçük Menderes Valley has been published and is of relevance here (Meriç 2009).

27 Luke et al. 2015; Совв 2016; Roosevelt and Luke 2017. Additionally, for the pre- and proto-history of the classical region of Lydia, cf. Roosevelt 2010. this contribution. Prehistoric research has never been the primary focus of investigations in the region around famous Pergamon, including the complete Bakırçay Valley. Aside from daily trips by W. Dörpfeld in 1908 and K. Bittel in the $1940 \mathrm{~s},{ }^{29}$ our information about its prehistory has generally been based on the survey of J. Driehaus, the results of which were published as one article in $1957 .{ }^{30}$ Subsequent research activities focused on periods of classical antiquity and the intensive excavations of the Hellenistic citadel of Pergamon.

This lack of systematic research in the valley made it an almost terra incognita of prehistory and provided an impetus for an archaeological and environmental survey project focused on the prehistory of the environs of Pergamon. Based on a broad spectrum of archaeological, archaeometric, and geo-archaeological analyses of previously discovered finds as well as new materials and sites, the study aimed at providing up-to-date and essential data about the prehistory of the region. The project focused on trying to discern a potential system of settlements and its change through time, its environmental context, as well as access to raw materials based on the location of potential resources in the region. Additionally, the evaluation of old and new data has allowed the definition of a new local ceramic sequence and its integration into the wider Aegean-Anatolian world.

The new survey of the prehistoric activity was initiated in 2007 and conducted between 2008 and 2014 by B. Horejs in cooperation with F. Pirson and the Pergamon excavations of the German

\footnotetext{
Luke et al. 2015; PAvúk and Schubert 2014.

Dörpfeld 1908; Dörpfeld and Hepding 1910; BitTel 1950.

30 Driehaus 1957.

31 For methodologies and analyses, see the annual reports Horess 2009; 2010b; 2011a; 2012; 2013; 2014b; Horess et al. 2015.
} 


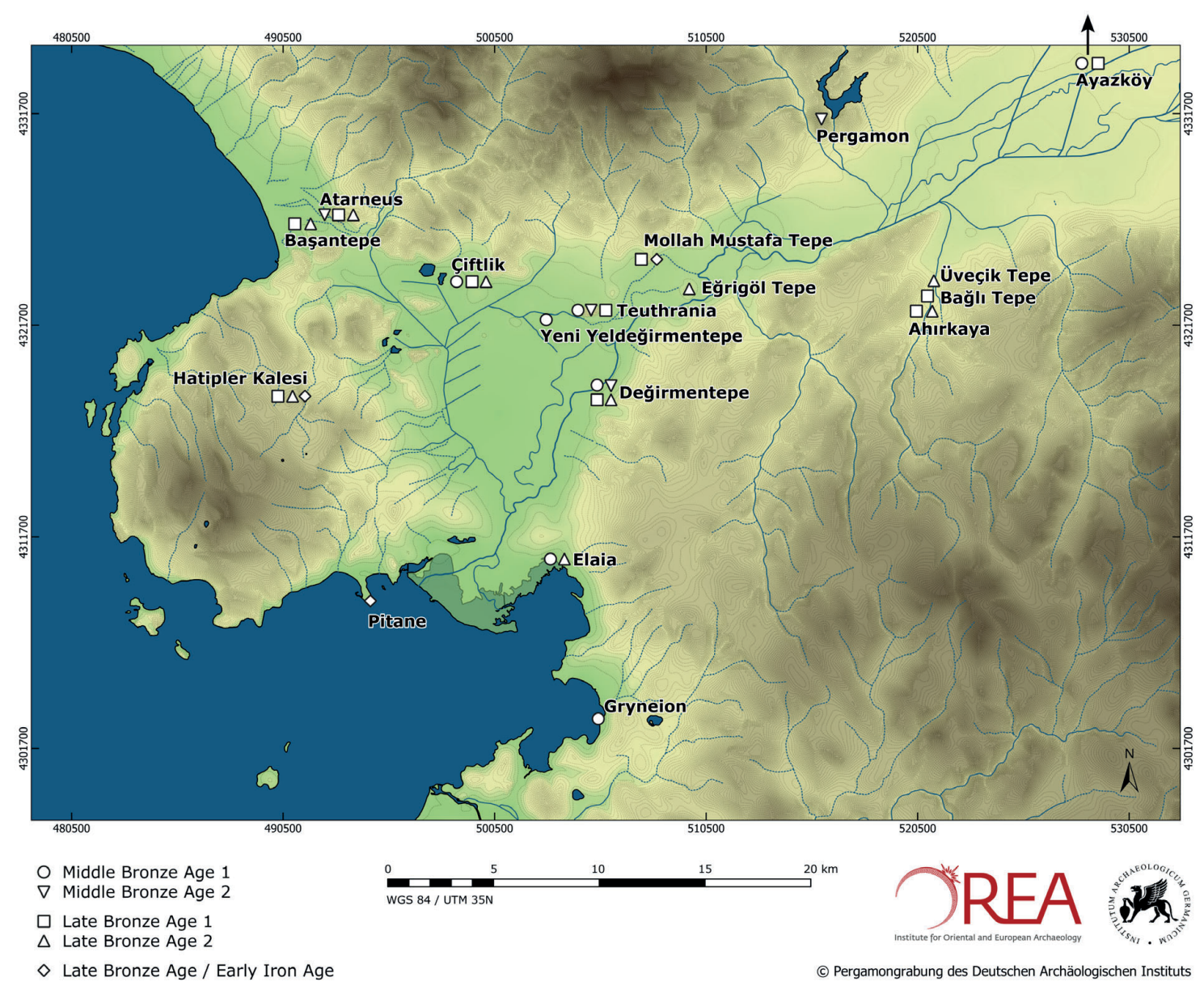

Fig. 2 Map of the central and lower Bakırçay Valley with all known 2nd millennium BCE sites (Map by M. Börner/OREA)

Archaeological Institute (DAI) in Istanbul. ${ }^{31}$ The documentation has been completed for all material categories and the sites, but additional analyses are still underway. Aside from the annual reports, broader results including the identification of new sites, settlement patterns, chronology, and environmental conditions have already been published. ${ }^{32}$ Parallel survey investigations by M. Zimmermann and F. Pirson, focusing on the later periods, provided additional data, ${ }^{33}$ which were partially included in our analyses.

The perennial surveys combined several methods in the field, adapted to the environmental conditions and experiences over the years (Fig. 1). The massive fluvial sedimentation of the valley plain and shifting river-channels were analysed and dated by core-drillings. These results demonstrate the limited areas for prehistoric settling in the valley, which was in focus in the first years of the project. The visible volcanic mounds (tepes) were intensively investigated with a bundle of methods, including surface collections in grids (e.g. Yeni Yeldeğirmentepe) or areas (e.g. Değirmentepe) depending on the natural conditions. Within these intensive surveys, all archaeological materials were collected and documented to offer a solid statistical fundament of material analyses and site interpretation. Accompanying drillings and geophysical surveys were conducted in the restricted areas of preserved cultural layers of these sitebased surveys. Additional extensive surveys along the edges of the Bakırçay Valley and its side valleys and hinterland formed the starting point of the second phase of the survey project. Extensive

32 Horess 2009; 2010a; 2010b; 2011a; 2011b; 2012; 2013; 2014a; 2014b; 2014c; Horess et al. in press.

Pirson and Zimmermann 2014, with further references. 
measuring, GIS surveys, aerial-map analyses as well as field studies of landscape characteristics with geological and geographical experts provided data for modelling potential settlement zones aside the Bakırçay Valley plain in the Gümüşova Valley, all published in the annual reports. These potential human activity zones were extensively surveyed, followed by intensive site-based surveys at archaeological find spots. These investigations included again systematic intensive surface collections in grids or areas, drilling cores and geophysical surveys in selected zones. The combination of various geoarchaeological survey methods and landscape modelling with systematic site-based surface collections offer a solid basis of data for further interpretations. Regarding the prehistory in the Bakırçay Valley, these data represent the state-ofthe-art survey outcome, before modern agriculture is expected to destroy these last remains of prehistoric activities in the region.

Altogether, 16 sites dating to the $2^{\text {nd }}$ millennium BCE can now be identified in the vicinity of Pergamon (Fig. 2): Gryneion, Elaia, Pitane, Hatipler Kalesi, Başantepe, Atarneus, Çiftlik, Değirmentepe, Teuthrania, Mollah Mustafa Tepe, and Erigöl Tepe in and around the lower Bakırçay Valley, ${ }^{34}$ Pergamon, Ahırkaya, Bağlı Tepe, and Üveçik Tepe in the central part of the valley (including the side valley of Gümüşova), and Ayazköy in the upper valley. Some of them have been analysed intensively with detail mapping and on-site documentation, geological investigations (drillings) as well as geophysical surveys. All of them provided archaeological finds, which were studied in detail. The Neolithic, Chalcolithic and Early Bronze Age (EBA) finds have been processed by Barbara Horejs and her team, the potential MBA and LBA finds by Peter Pavúk. The analytical description of pottery has been embedded in a locally developed system of wares and fabrics. ${ }^{35}$ Systematic archaeometric analyses of the pottery have also been conducted in cooperation with Sarah Japp and Hans Mommsen. ${ }^{36}$

Overall, the present study is based on 195 (new survey) and 102 (old surveys) diagnostic pieces of ceramics from all 16 sites of the $2^{\text {nd }}$ millennium $\mathrm{BCE}$, and these also form the basis of the results presented in the following pages.

34 Yeni Yeldeğirmentepe yielded possibly one MBA piece, but is otherwise primarily an EBA site.

35 For details of this system see HoRejs 2010.

\section{Chronology and periodisation of the $2^{\text {nd }}$ millen-} nium BCE Bakırçay Valley

One of the major aims of the survey was to discern the potentially changing settlement dynamics within the valley. In order to do so, one had to assess the fragmentary survey material as chronologically closely as possible. With no stratigraphic sequence excavated in the area, one had to turn for comparanda to the closest stratified site, which is Troy. The typological discussion and the related dating of the fragments thus followed in broad terms the system developed by Peter Pavúk at Troy, which had to be adjusted to fit the local spectrum, as the Troad seems to have belonged to a different ceramic group more strongly influenced by the Mycenaean pottery. ${ }^{37}$

For the Western Anatolian periodisation and chronological system, the present article follows the one presented by Peter Pavúk in the 2011 'Nostoi' conference in İstanbul, ${ }^{38}$ which was based mainly on the development of the local Anatolian ceramics. It cannot be synchronised one-to-one with the neighbouring systems, since it does not follow the standard tripartite division. Such a division does not suit the ceramic development of Western Anatolia (as is also the case of Cyprus). The new periodisation divides MBA into a main phase (MB 1) and a transitional one (MB 2), has LBA start around $1700 \mathrm{BCE}$, divided principally in LB 1 (roughly equivalent to LH I and II in the Aegean periodisation and the Old Kingdom period in Central Anatolia) and LB 2 (equivalent to LH IIIA and IIIB in the Aegean periodisation and the period of the Hittite empire in the east), with a potential of further subdivision into $\mathrm{LB} 1 \mathrm{~A}$ and $1 \mathrm{~B}$, resp. $2 \mathrm{~A}$ and $2 \mathrm{~B}$.

The MBA (c. 2000-1700 BCE) is characterised by the predominance of Red Slipped Wares, accompanied by Plain Wares and Plain Burnished Wares. Characteristic shapes are a range of carinated bowls, shallow as well as deeper, mostly lipless. The Red-Cross decoration inside such bowls has not been identified so far in the Bakırçay Valley, but since it is common at both Troy and Beycesultan, one can expect it in the Bakırçay Valley as well. Not evidenced in the Bakırçay Valley is likewise the distinctive applied 'omega' decoration;

\footnotetext{
36 First results of the EBA pottery production are already completed: Horess, JAPp and Mommsen 2018.

37 РАvÚк 2015, 96, Fig. 9.

38 PAvÚk 2014, Taf. 5; 2015, Fig. 1.
} 
however, its chronological position is unclear and it could just as well represent the equally absent EB 3 period. Bead-rim bowls should also begin to be produced somewhere during the MBA, with earlier bowls of a rounded (Fig. 3a: 3) rather than carinated shape. However, very few fragments of this early (rounded) variant have actually been identified in the Bakırçay Valley. The only shape recognised as belonging to the MBA in the present survey is a carinated bowl with low, relatively upright upper body, an obliquely scraped lip and a vertically pierced lug on the shoulder (Fig. 3a: 5).

The next identifiable phase is the end of MBA and the beginning of LBA. The transition between the periods is hard to draw in the ceramic record. The rounded bead-rim bowl is by now a popular shape, occurring in Red Slip and Red Wash Wares, but now it is also represented by the newly introduced Anatolian Grey Ware (AGW), which slowly gains popularity at this point. Full blown LB 1 (c. 1700-1400 BCE) in ceramic terms comes with the widespread introduction of various carinated bowls, usually with ribbed/ridged decoration and in most cases with upright shoulder, which can be concave (Fig. 3a: 2, 7-10). This includes Bead Rim bowls, which are now usually carinated (Fig. 3a: 4). Early on, the light-faced variant of the Grey Ware, which we prefer to call the Orange Ware, also appears, but then continues in relatively low numbers until the end of the Bronze Age, when its number seems to go up.

LB 2 (c. 1400-1200 BCE) is less easily identified, since we do not know the lifetime of shapes introduced during LB 1. Various krater-like shapes (Fig. 3b: 19) can be most likely dated already to LB 2, judging by assemblages from Troy and by a general increase of the popularity of the crater shape on the Greek Mainland, a trend likely related to the changing banqueting habits. Mentioned should also be simple hemispheric lipless bowls (Fig. 3b: 15) and carinated cups with concave upper body (Fig. 2b: 18). Various local painted wares should also be of LB 2 date, as for example those from Aphrodisias and to a lesser extent also from Beycesultan. ${ }^{39}$ None of these have been recorded in the Bakırçay Valley so far, but the next best representatives come from Kaymakçı and

\footnotetext{
Marchese 1978; DedoĞLou and KonaKÇı 2015

Roosevelt et al. 2018, Online Fig. 7.

${ }^{41}$ Hanfmann 1967, Figs. 9-11; Ramage 1994.
}

date to the later stages of LB $2 .^{40}$ Painted decoration is also reported at Sardis, with the finds dating to the end of the Bronze Age. ${ }^{41}$

How should one imagine the period after c. 1200 BCE? One could term it LB 3, following the Aegean periodisation, but EIA was also suggested, in line with the Central Anatolian cultural developments, or the Thracian ones, for that matter. ${ }^{42}$ A transitional LB/EIA phase would serve as well. It is very likely that the production of wheelmade pottery continued, as evidenced in the strata of Troy VIIb, but became complemented by various handmade burnished wares. ${ }^{43}$ What is not clear, however, is to what extent the rise in popularity of such handmade burnished wares can be witnessed also outside of Troy. There are barely any relevant sites found to date (cf. Fig. 3b: 21 and 25 for the possible relevant finds from the Bakırçay Valley). Yet, that a systemic collapse of some kind after c. $1200 \mathrm{BCE}$ was followed by a gradual return to handmade household-based production of pottery is certainly not an unlikely scenario. The problem is that many of the LB 3 wheel-made shapes at Troy are part of the incipient Aeolian set of shapes, which remain restricted to the coast and the littoral islands in front of it. ${ }^{44}$ It is not clear to what extent such shapes are expected to have been used further inland.

\section{Wares and shapes in the $2^{\text {nd }}$ millennium $B C E$ Bakırçay Valley}

During the $2^{\text {nd }}$ millennium BCE, the most common ware was the Grey Ware (74\%), followed by the Orange Ware (13\%), Schamotte Ware $(2 \%)$, Plain Ware (2\%), and two types of Coarse Wares $(4 \%)$, as well as five types of Pithos Wares (3\%) (Fig. 4). Regarding clear imports from more distant regions, the only one that stands out is a verified Mycenaean fragment. Whereas it was easier to distinguish different fabrics for the relatively coarser wares, it turned out problematic for the finer wares. Paste and temper show certain variability, but the transitions between the respective fabrics are just too fluid to establish clear cut divisions, rather they represent a gradient along a scale rather than clear-cut categories.

\footnotetext{
42 Well summarised in HNILA 2012, 13. Admittedly, the issue was more acute at Troy, where all three spheres converged.

43 Blegen et al. 1958; HNILA 2012.

44 BAYNe 2000.
} 

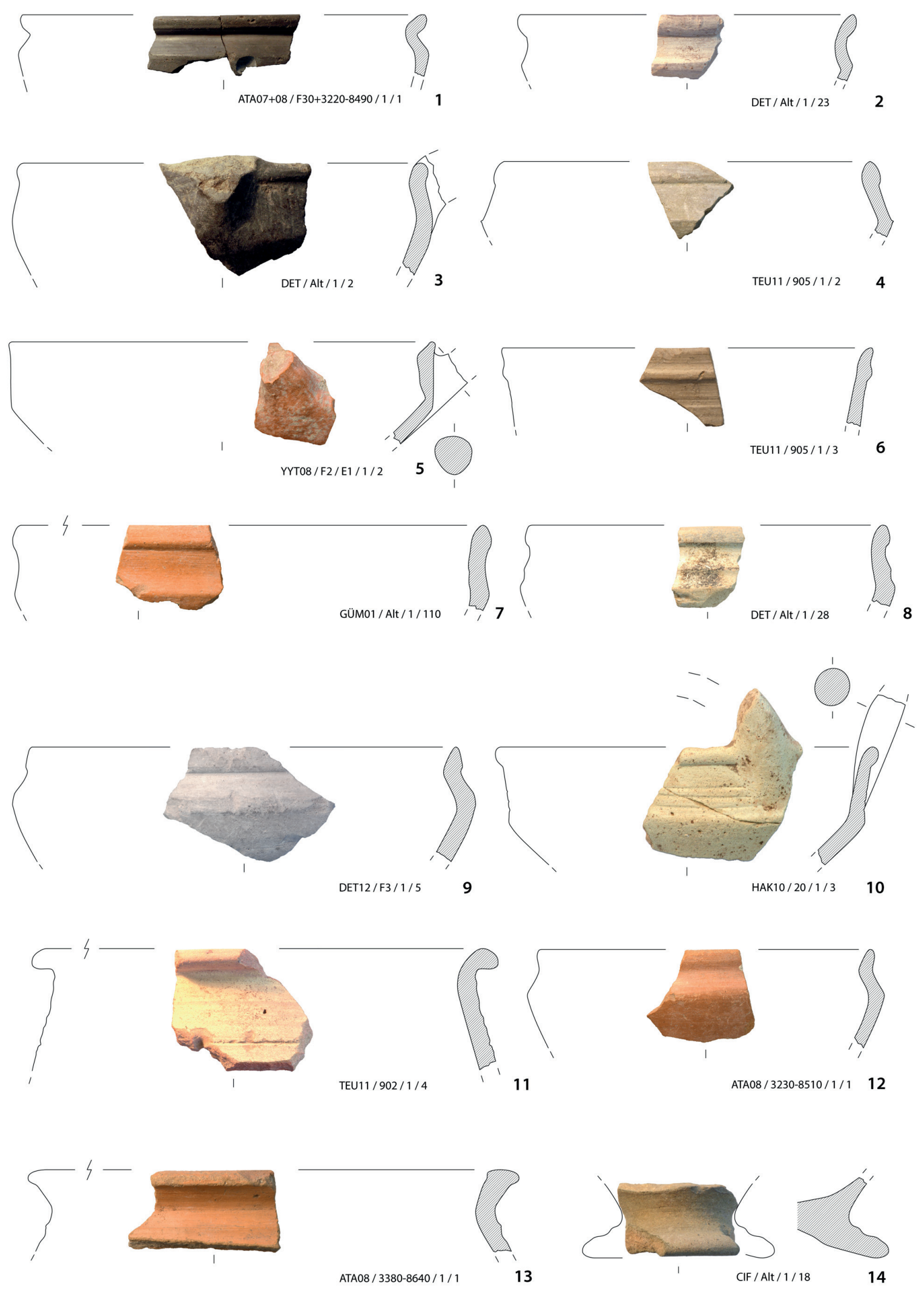

Fig. 3a Bakırçay Valley. Typological overview of the MB and LB 1 ceramic shapes from the survey (Drawings and photographs by Th. Urban/OREA) 


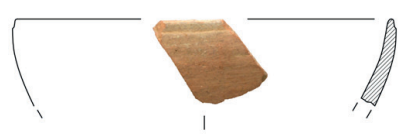

15

GÜM07_12/F1/1/12

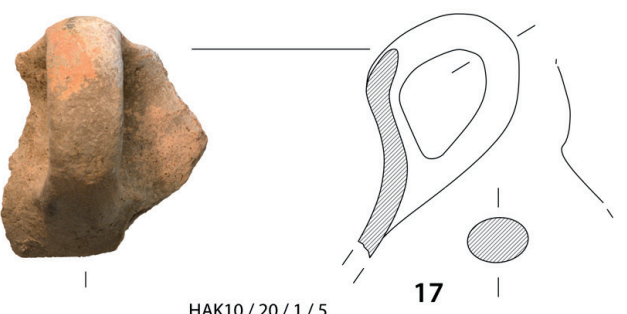

HAK $10 / 20 / 1 / 5$

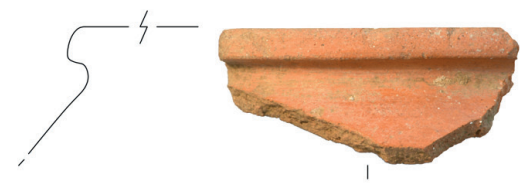

$\mathrm{DET} 12 / \mathrm{F} 7 / 1 / 2$

19

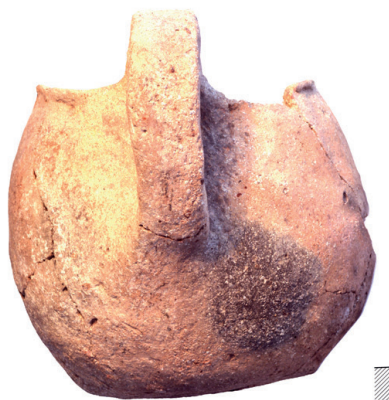

MMT10/200b/1/1

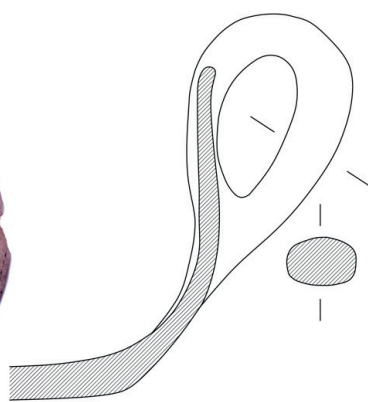

21

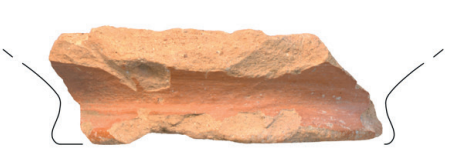

।

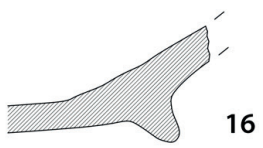

ERT11/200/1/4

16
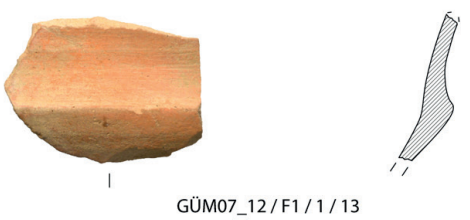

18
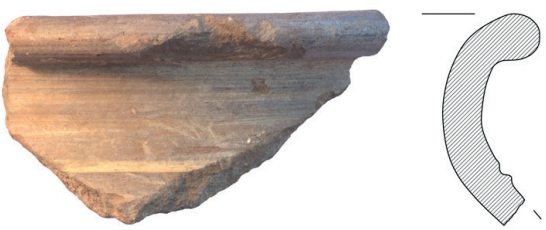

DET / Alt / $1 / 48$

20
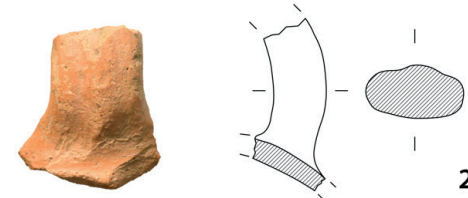

GÜM07 $12 / F 1 / 1 / 10$

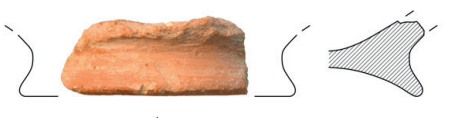

DET / Alt / $1 / 81$

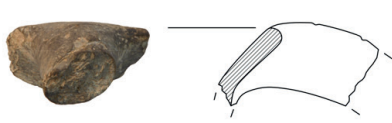

HAK $10 / 20 / 1 / 4$

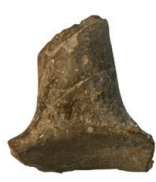

24

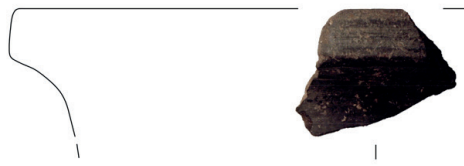

HAK10/20/1/1

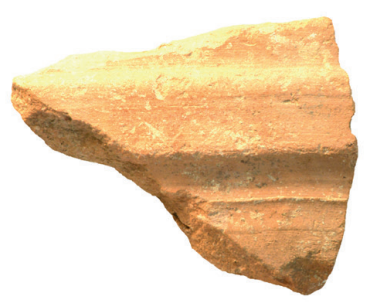

DET12/F3/1/21

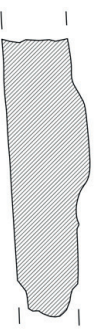

26
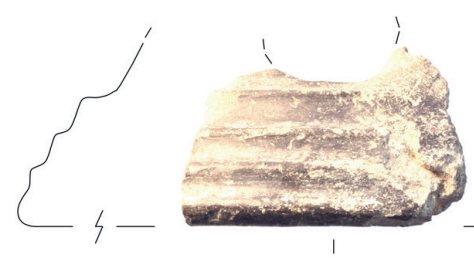

DET / Alt / $1 / 83$
25

22

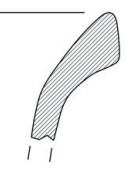

Fig. 3b Bakırçay Valley. Typological overview of the LB 2 and LB 3 ceramic shapes from the survey (Drawings and photographs by Th. Urban/OREA) 


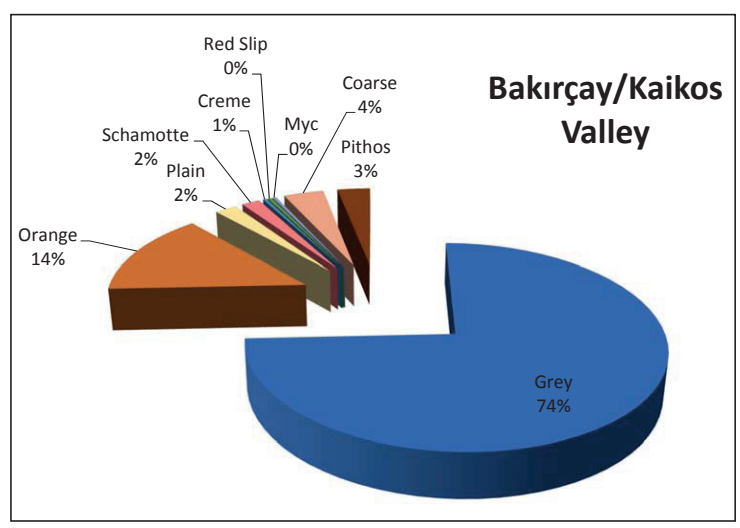

Fig. 4 Bakırçay Valley. Frequency of ware occurrences from the survey ceramics $(n=292)$

The Grey Ware is roughly the standard version of what is customarily called the Anatolian Grey Ware, with well burnished soapy surface (Fig. 5). ${ }^{45}$ There are several variants/fabrics, and even though clear-cut distinctions are not always possible to make, there is a visible variation. Just as elsewhere in Northwestern Anatolia, the sites in the Bakırçay Valley yielded its light-faced counterpart, termed here the Orange Ware (Fig. 6). Under the influence of the Trojan nomenclature, one would instinctively call it Tan Ware; however, given differences in the fabric, surface treatment, and colour, it was decided to distinguish it from the Trojan Tan Ware, which really seems to be limited to just a few sites in the Troad. ${ }^{46}$ The Grey and Orange Wares seem to have comprised most of the local ceramic output, making up to $87 \%$ of the recovered ceramic fragments. To what extent this high number reflects a real trend is a different matter, which will be discussed below. In terms of shapes, the Grey Ware comprises virtually all existing shapes (except for pithoi), especially the drinking and serving services, and above all bowls. Orange Ware, even though less common, includes more or less the same spectrum. It is interesting that there are similarities to the Trojan trend, as the Orange Ware becomes more popular over time. But unlike at Troy, where the Tan Ware emerges only at the end of LB 1 and becomes pop-

45 French 1973; Schachner 1994/95; PAvúk 2008.

46 PAvúk and Schubert 2014. See also the insightful discussion in Schachner and Meriç 2000.

47 This was also confirmed by chemical analyses conducted by H. Mommsen, to be published together with S. Japp. ular in LB 2, the Orange Ware started early on, in early LB 1, together with the Grey Ware (Fig. 7).

The other fine wares make up just a handful of sherds each. Plain Ware is the standard fine, porous, and barely tempered ware with a plain surface, represented sparsely in shapes such as cups, bowls, jugs, and kraters. Schamotte Ware was found at only four sites (Değirmentepe, Erigöl Tepe, Hatipler Kalesi and Ayazköy) in one fragment each, and being visibly different from the rest of the lot, it is our main candidate for a possible import (Fig. 8). Its main characteristic is the medium-sized red angular particles identified preliminary as 'Schamotte'. The surface of almost all fragments recovered is worn, but seems to have been red, likely a result of applying slip. The recovered fragments suggest that mainly bowls and kraters were produced in this ware. Creamy Ware occurred in only one instance, a fragment of a small amphoroid krater, distinguished by its creamy-coloured slip on a porous reddish fabric tempered by calk particles. This piece from Teutrania is also most likely an import.

The place of origin of Schamotte Ware and Creamy Ware is currently not known, but it is likely not very distant. On the contrary, one painted fragment from Atarneus can be readily identified as Mycenaean Decorated Ware, judging by the fabric of non-local character and assuming that it comes from the most common place of origin of imported Mycenaean pottery in Western Anatolia, the Mycenae-Berbati workshop in the Argolid. ${ }^{47}$ It is a linear rim of a kylix (FS 256/257), probably decorated with octopus (FM 21), but the assessment is not secure due to its fragmentary character. Based on parallels, the piece should be of a $\mathrm{LH}$ IIIA2 date (Fig. 9) ${ }^{48}$ Embracing all known finds from the Bakırçay Valley, the well-known Mycenaean stirrup jar from Çandarlı (Pitane) should be mentioned here as well, even though the authors have not personally studied it. ${ }^{49}$ The complete jar has been discussed as a potential import from the Dodecanese or Cyclades, dating to LH IIIC..$^{50} \mathrm{~A}$ slightly forgotten Mycenaean fragment supposedly from Elaia, was mentioned by Bayne. It is a rim of a kylix, LH IIIA2 in date, with a flower design

\footnotetext{
48 Mountjoy 1999, 272, Fig. 90: 112 (Ayios Stephanos, Laconia).

49 Perrot and Chipiez 1894.

50 Mountjoy 1999; for all publications mentioning that vessel, see HoreJs 2014c, 108.
} 


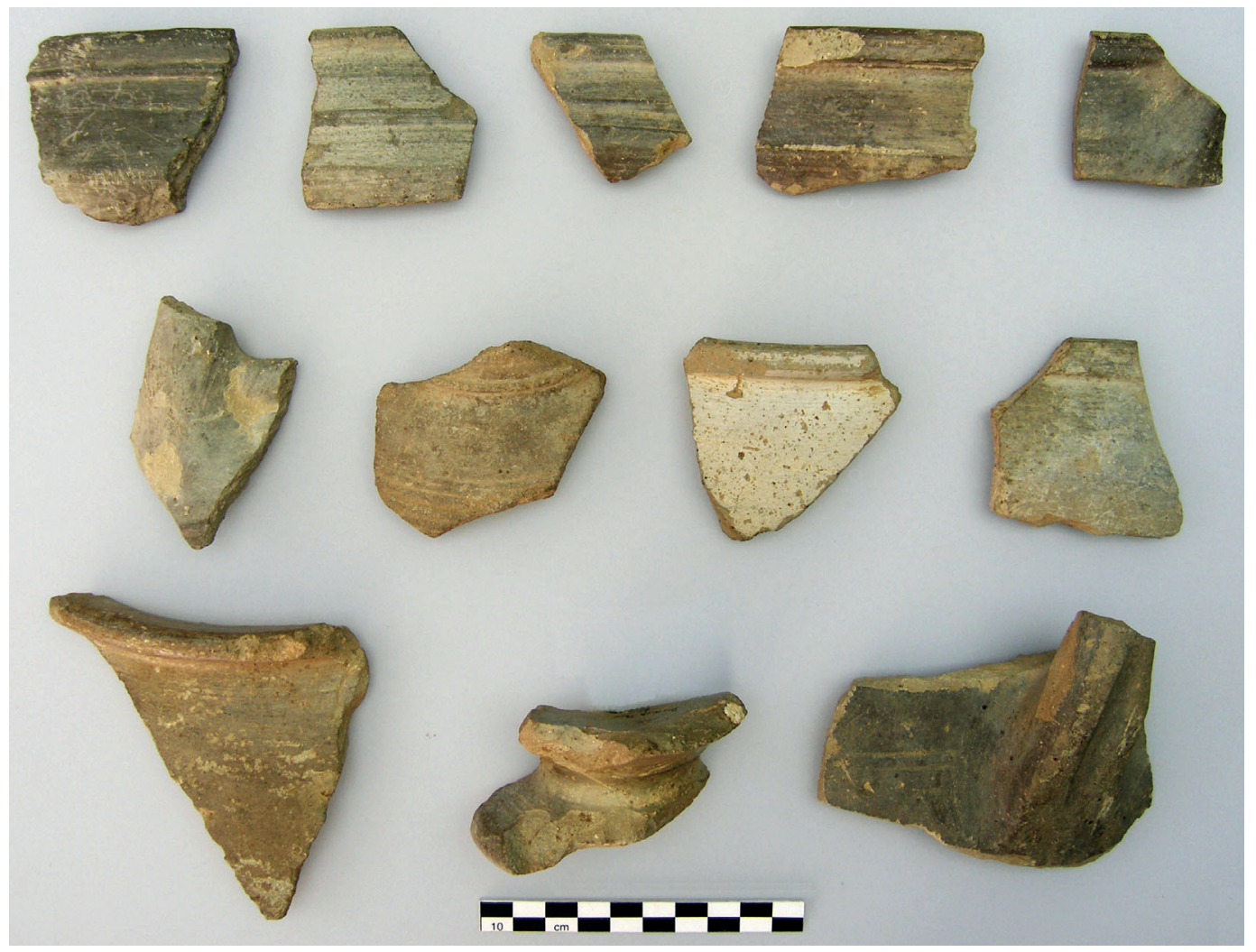

Fig. 5 Değirmentepe. Selection of Grey Ware fragments from the old surveys (Photo by G. Pastirčák)

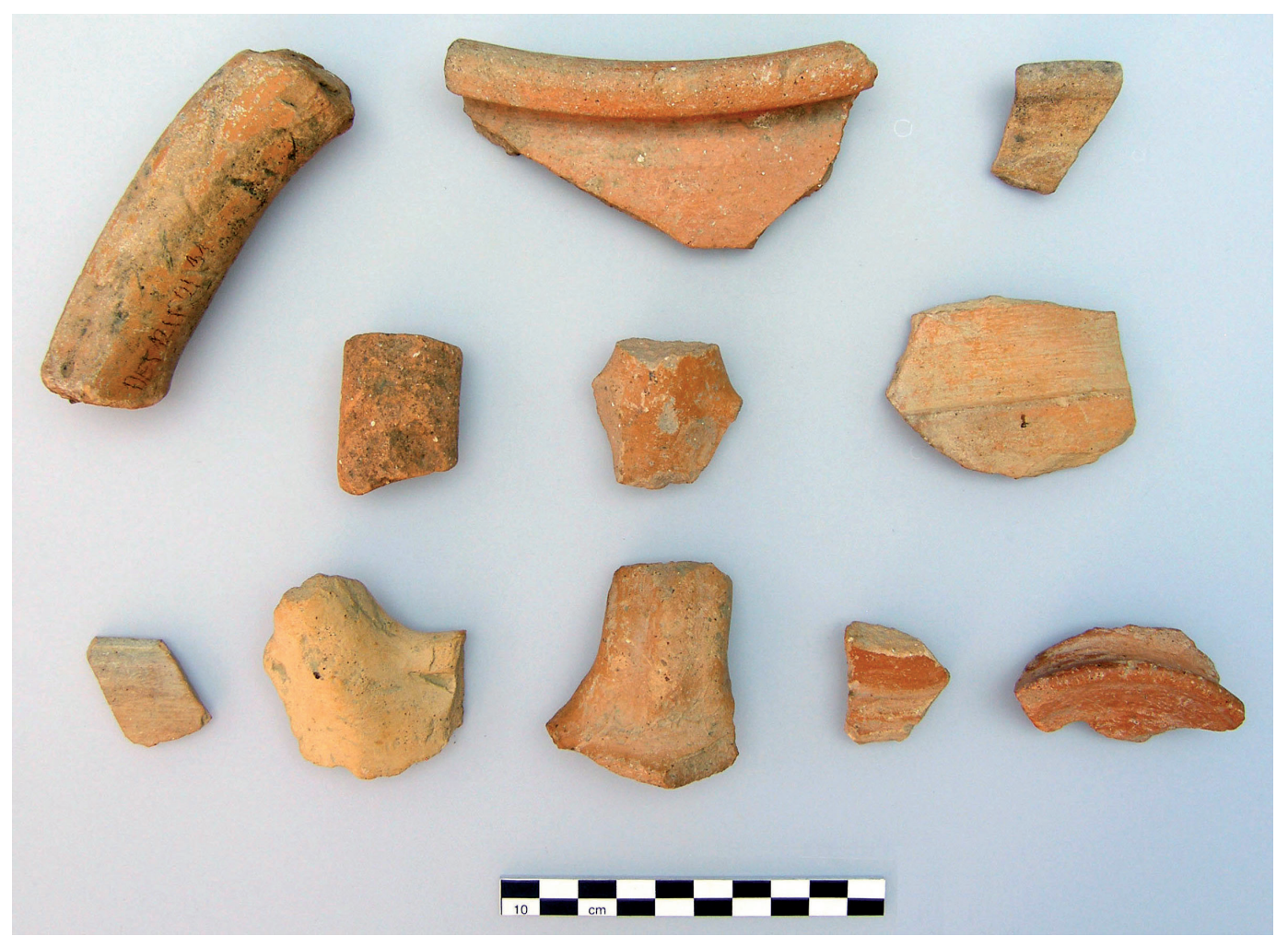

Fig. 6 Bakırçay Valley. Selection of Orange Ware from the new survey (retrieved from sites of Değirmentepe and Ahirkaya) (Photo by G. Pastirčák) 


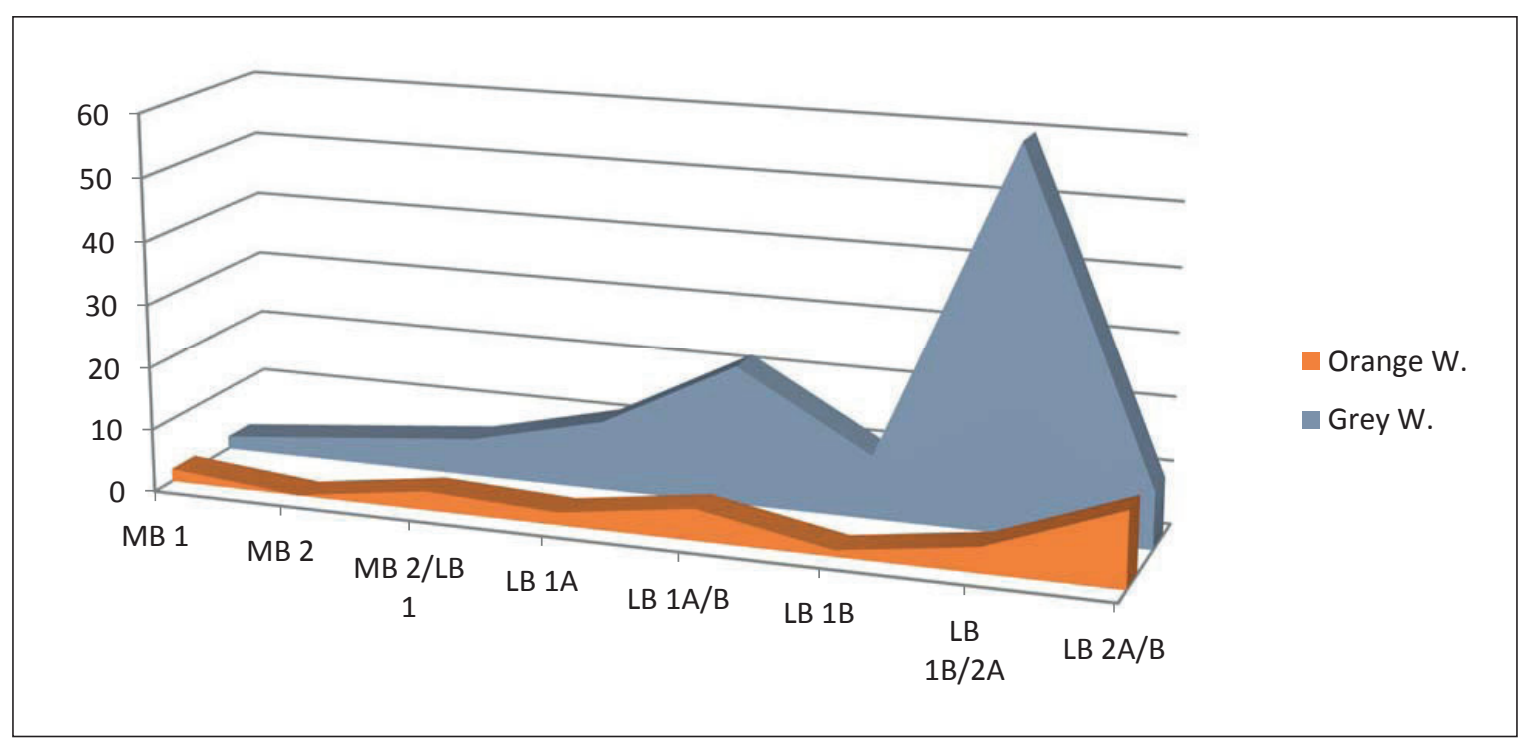

Fig. 7 Bakırçay Valley. The changing ratio of the Grey and Orange Wares over time $(n=153)$

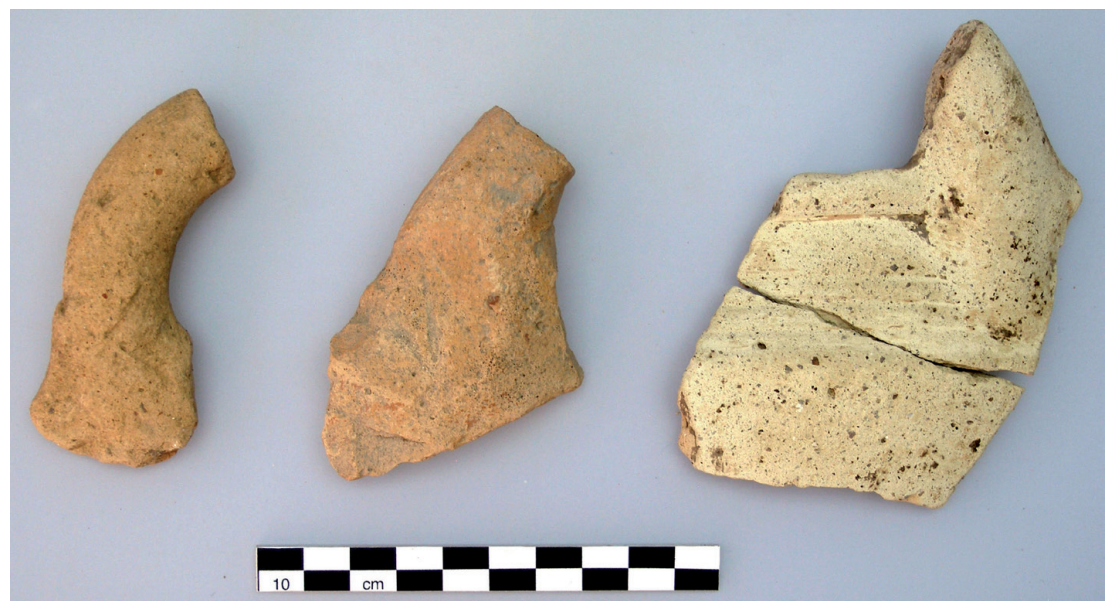

Fig. 8 Bakırçay Valley. Selection of Schamotte Ware from the new survey (from sites of Değirmentepe and Hatipler Kalesi) and the old survey (from Ayazköy) (Photo by G. Pastirčák)

The coarser spectrum yielded two standard types of Coarse Wares, both brownish, with the one variety a bit more crumbly and the other one more compact. The shapes comprise mainly cooking pots. An interesting feature was the identification of five distinctive Pithos fabrics, which might indicate that a variety of local pithoi were produced through time. Both of these observations deserve further discussion here. The

identified as Attic by F. Stubbings (Fig. 10). ${ }^{51}$ One wonders if that is the unillustrated fragment that Mellaart had mentioned in his Anatolian Trade with Europe, which in turn was then quoted by both Mee and Kelder in their overviews of the distribution of Mycenaean pottery in Western Anatolia. ${ }^{52}$ The authors believe that such a scenario is very likely and are, therefore, presenting its identification here as such.

51 BAYNe 2000, 91, Note 385. The location of the fragment is unknown today. The original PhD thesis by BAYNE (1963, Fig. 28: bottom) contained also a photograph of the sherd, which was for technical reasons not included in the Asia low frequency of coarse wares among the survey finds is somewhat remarkable and cannot reflect the actual LBA state. In case of old material collections, one could suspect that they did not keep the coarse wares as part of collected survey material. The new surveys with intensive on-site collections, however, also provide small assemblages of Coarse Wares (e.g. Değirmentepe). Troy and the Troad are a good case point. At the better

Minor Studien publications. We would like to thank N. Bayne for the kind permission to republish the fragment here.

52 Mellaart 1968, 188; Mee 1978, 127; Kelder 2006, 56. 


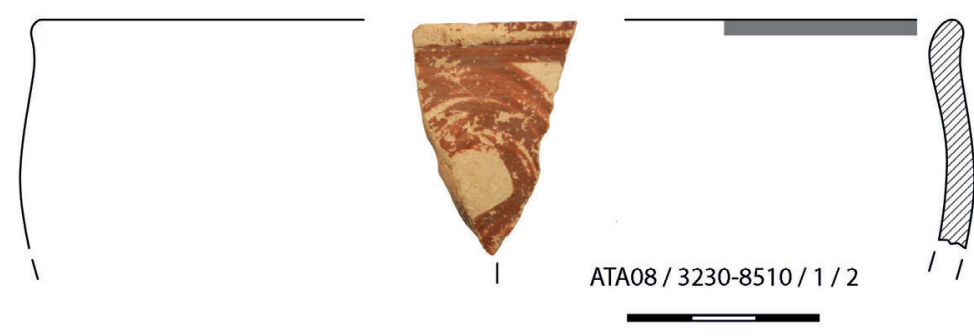

Fig. 9 Atarneus. Mycenaean Decorated Ware (Drawing and photograph by Th. Urban/OREA)

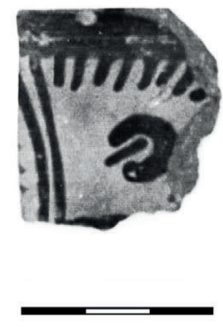

Fig. 10 Elaia (?).

Mycenaean Decorated Ware (BAYNe 1963, Fig. 28 bottom) quantified settlement evidence from Troy VI, the share of Coarse Wares was generally around $20 \%{ }^{53}$ However, a recent non-intensive survey of the Troad yielded almost no diagnostic LBA coarse ware at all (c. 1\%). ${ }^{54}$ This begs for two explanatory models: 1) the coarser wares have a greater tendency to decay on the surface, or 2) even if we do recover them, it is often impossible to date them to a specific time period. ${ }^{55}$ In comparison to the Troad, the Coarse Wares that comprise $4 \%$ of all pottery recovered by the present Bakırçay Valley survey can be explained by the more intensive surveying methodology and recovery strategy. This low number is even more startling when we take into account that almost all Coarse Ware and pithos fragments come from the best preserved and most intensely surveyed $2^{\text {nd }}$ millennium BCE site in the region, Değirmentepe.

In contrast to Coarse Wares, pithoi are notoriously hard to quantify even within excavated settlements, as their distribution within sites varies. There are areas with many pithoi, while other areas have none. ${ }^{56}$ It is a known fact that the production of larger pithoi is a highly specialised craft. Even more so, it is interesting that all recovered $2^{\text {nd }}$ millennium BCE fragments are from the same site, Değirmentepe. One could again propose various scenarios: 1) the five different pithos fabrics represent different contemporaneous workshops, but all from the same site and are thus local, 2) various contemporaneous workshops but some of them can be imports from other production centres, and 3) since none of the fragments can be

PAVÚK 2014, 231-235.

54 PAvÚK and Schubert 2014, 866-871. There were just 4-5 Coarse Ware pieces (other than pithoi) out of the 292 catalogued fragments in the Troad survey.

55 Some of the Byzantine Coarse Ware looks surprisingly 'prehistoric'. closely dated, the variety of pithoi fabrics can indicate the longer period of occupation activity at the site during the MBA/LBA periods (the lifespan has been established to c. 500 years based on the collected fine wares). To provide a comparative example, at Troy the petrographic analysis, confirmed independently by NAA results, showed that practically all of the hundreds of pithoi recovered from Late Troy VI and VIIa contexts were imported from the central Scamander Valley (likely floated down the river towards Troy). ${ }^{57}$

Taking the whole corpus together (irrespective of the date), it is remarkable that bowls (both shallow and deep) make up $51 \%$ of all identifiable shapes (Fig. 11). Whereas the settlement material from Troy VI comprised c. $30 \%$ of bowls, the survey material from the Troad showed somewhat higher numbers but still not $50 \%$. The difference can be likely explained by the missing Coarse Wares (and the related pots and jars produced in them) in both of the surveys. ${ }^{58}$ Still, $51 \%$ of the entire assemblage is a surprising number and shows the importance of bowls for the people living in the Bakırçay Valley. Interesting is also the high number of jugs that comprise $16 \%$. If flasks are added to this number, we reach $20 \%$. However, the quantified jugs and flasks from the stratified material from Troy VI did not reach more than $8 \%{ }^{59}$ Again, quantifying jugs is not an easy task. The narrow necks and rims do not create many rim-fragments in the archaeological record. If only those indicative fragments are calculated, we would have barely any in the Bakırçay survey.

\footnotetext{
Thumm-Doğrayan et al. in press.

77 KibaroĞLu and Thumm-DoĞrayan 2013; Grave et al. 2013.

58 Pavúk 2014, 355-356, Abb. 144-16; PAvÚk and Schubert 2014, 882-901.

59 PAvÚK 2014, 355-356, Abb. 144-16.
} 


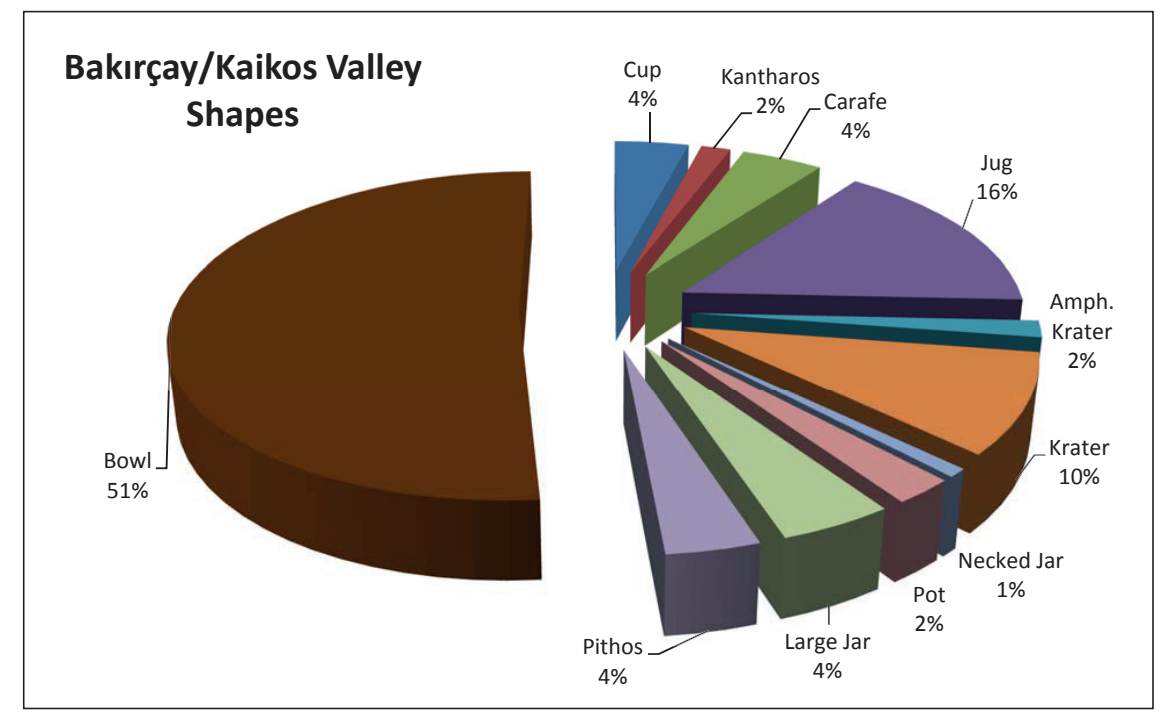

Fig. 11 Bakırçay Valley. Frequency of shape occurrences of retrieved survey finds ( $n=126)$

What can be found, however, are the vertical oval and rounded handles. Being relatively massive, they tend to weather well and can also be easily spotted in the field. To balance the lack of the rims, therefore, one needs to count in the jug-handles as well.

The rest of the shape categories show a relatively common distribution: various cups (4\%), kantharoi $(2 \%)$, kraters $(10 \%)$, amphoroid kraters $(2 \%)$, pots $(2 \%)$, jars $(5 \%)$, pithoi $(4 \%)$. But even in this case, one could wonder: at Troy, various cups made up to $25 \%$ and various jars and pots even $30 \%$ of the assemblage. In both cases, one encounters the survey bias of small shapes, such as cups, tending to be either already destroyed or overlooked by the surveyors. The lack of pots and jars must therefore be related, in turn, to the general lack of Coarse Wares among the retrieved material (see above).

In sum, it can be suggested that the $2^{\text {nd }}$ millennium BCE pottery in the Bakırçay Valley more or less shows a straightforward development from final EBA to final LBA, with several definable subdivisions, such as $\mathrm{MB}, \mathrm{MB} / \mathrm{LB}$ transition, $\mathrm{LB}$ 1 and LB 2, based on the typological development of ceramics and comparisons with the surrounding areas and mainly the Troad. The ceramic definition of local EB 3 still needs to be defined in this area. While the EB 1 and EB 2 pottery is predomi- nantly (if not completely) handmade, ${ }^{60}$ the $2^{\text {nd }}$ millennium $\mathrm{BCE}$ potters were acquainted with the potter's wheel at least to some degree. With the increasing awareness concerning the complexity of the wheel-made pottery production in the Aegean, ${ }^{61}$ it can be stated that none of the local production discussed in this paper is a proper wheelmade technique. However, there is a gradual introduction and employment of wheel-finishing to various degrees. Given that in the Bakırçay Valley there is so far no proper evidence for the Trojan A2-Plates and shapes such as the depas amphikypellon, which elsewhere indicates the uptake of the potter's wheel (at least in some form) during EB 2, one has to wonder when and to what extent this innovation came in. The model of a relatively conservative concept of pottery production in the Bakırçay Valley has already been discussed in light of detailed analyses of radiocarbon-dates from Chalcolithic and EBA sites. ${ }^{62}$ More targeted research needs to continue in order to be able to reconstruct the adoption of this technology.

In terms of wares and shapes, the bowls very much dominate the spectrum of shapes and one has to wonder, again, to what extent this reflects the method of retrieval of the assemblage. The MBA pottery is mainly red and beige in colour, changing to grey and orange in the LBA. It needs to be stressed that all of the fine wares are bur-

HoreJs et al. 2018, 28

61 Well summarised and put in context by CHOLEVA 2012.

\footnotetext{
62 SCHNeIDER et al. 2017; Horejs et al. 2018, 41.
} 
nished until LB 2 (and possibly even beyond), which seems to set Bakırçay Valley apart from the areas further to the south, where burnishing as a means of sealing the porosity of the surface gives way to various micaceous washes. ${ }^{63}$ High proportion of Grey Wares throughout the LBA also distinguishes the Bakırçay Valley from its southern neighbours.

\section{Habitation trends and settlement patterns}

The settlement dynamics can be reconstructed as follows. Local MBA (c. 2000-1700 BCE) is barely represented; possible candidates include Elaia, Grynaion, Çiftlik, Yeni Yeldeğirmentepe and Değirmentepe, and likely also Ayazköy located in the upper valley. The problem in addressing local MBA is that the typical representative materials, such as Red Cross Bowls or Red Slip carinated bowls with omega-shaped plastic decoration (EB3?), are absent. Unfortunately, even the one or two shapes identified typologically as belonging to MBA could also be of EIA date (Fig. 3a: 5). MBA (and for that matter EBA 3 as well) is thus very hard to identify in this area. Better identifiable is the next stage, tentatively termed 'Late MBA', which might possibly include also the earliest LBA (c. $1700 \mathrm{BCE}$ ), represented by the first appearance of Anatolian Grey Ware (AGW) and by rounded Bead-Rim Bowls and pattern-burnishing (Fig. 3a: 3). This stage is almost certainly evidenced on the Acropolis of Pergamon, ${ }^{64}$ but relevant fragments also come from Atarneus, Değirmentepe and Teutrania.

A major change happens during (with the onset?) the LB 1 stage (c. 1700-1400 BCE) when almost all of the sites identified within the survey show signs of occupation. Typical are a wide range of carinated ridged bowls, usually in AGW (Fig. 3a: 8). The next stage, LB 2 (c. 1400-1200 BCE) witnesses a slight decline in the number of sites, with only seven out of fifteen previously occupied sites yielding relevant finds: Atarneus, Başantepe, Çiftlik, Değirmentepe, Eğrigöl Tepe, Hatipler Kalesi, and Ahırkaya. We do not have enough spatial data to evaluate whether these seven sites grew in size during the LB 2 stage, but one could consider this pattern as a nucleation of

\footnotetext{
63 Well documented now in the stratified material from Kaymakçı (Roosevelt et al. 2018).

64 Radt 1992; Hertel 2011.

65 Pavúk and Schubert 2014; PavÚk et al. 2014.

66 PAvÚK et al. 2014, 116-117, Pl. XXXIIIa.
}

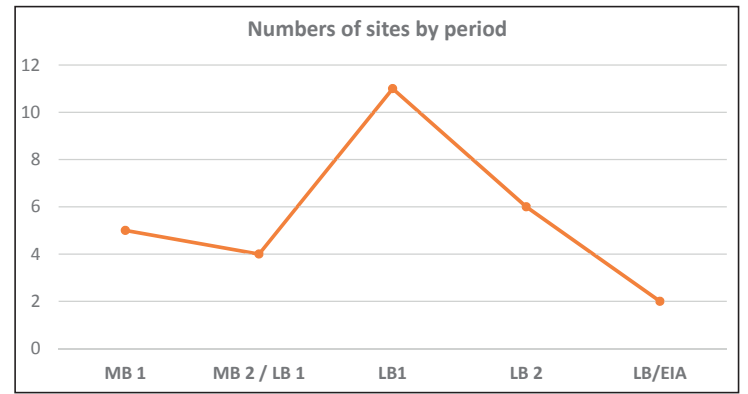

Fig. 12 Bakırçay Valley. Site distribution according to the identified periodisation

the previously more dispersed settlement pattern. The end of the $2^{\text {nd }}$ millennium BCE is again barely represented, now only with Hatipler Kalesi (Fig. 3b: 24), possibly also Mustapha Mulla Tepesi (Fig. 3b: 21). It is at a somewhat remote location high up on an isolated mountain, difficult to reach, which might be a contributing reason for its continued existence.

In its general outlook, the Bakırçay Valley fits very well the more general patterns observed in Northwestern Anatolia. While MBA is barely known, there are many LB 1 sites, a fewer LB 2 sites, and almost no sites of the LBA/EIA transition (Fig. 12). Here, again, the survey results from the Troad can serve as a good comparative case study, as they mirror the Bakırçay Valley evidence closely. ${ }^{65}$ It is also in the Troad that we see a certain correlation between the changing settlement patterns and the climatic reconstructions and archaeobotanical evidence. Simone Riehl showed that unlike during the end of the $3^{\text {rd }}$ millennium $\mathrm{BCE}$ and then the second half of the $2^{\text {nd }}$ millennium BCE, which show relatively clear evidence for drier periods, the second quarter of the $2^{\text {nd }}$ millennium BCE (our LB 1) seems, on the contrary, to be a period of a climatic optimum, as confirmed locally by the stable carbon isotope analysis as well. The values below $17 \% 0 \Delta \Delta^{13} \mathrm{C}$ can be considered indicative of a moderate to strong droughtstress on the plant growth during its grain-filling period. ${ }^{66}$ Since we do not have comparable levels of data input from the Bakırçay Valley, it is reasonable to present this possibility and assume similar conditions in the valley as well as all over Northwestern Anatolia. ${ }^{67}$ Better climatic condi-

\footnotetext{
7 Again, new research around the Marmara Lake, coordinated by John Marston (University of Boston), has the potential to yield new data in this respect as well; cf. Roosevelt et al. 2018.
} 


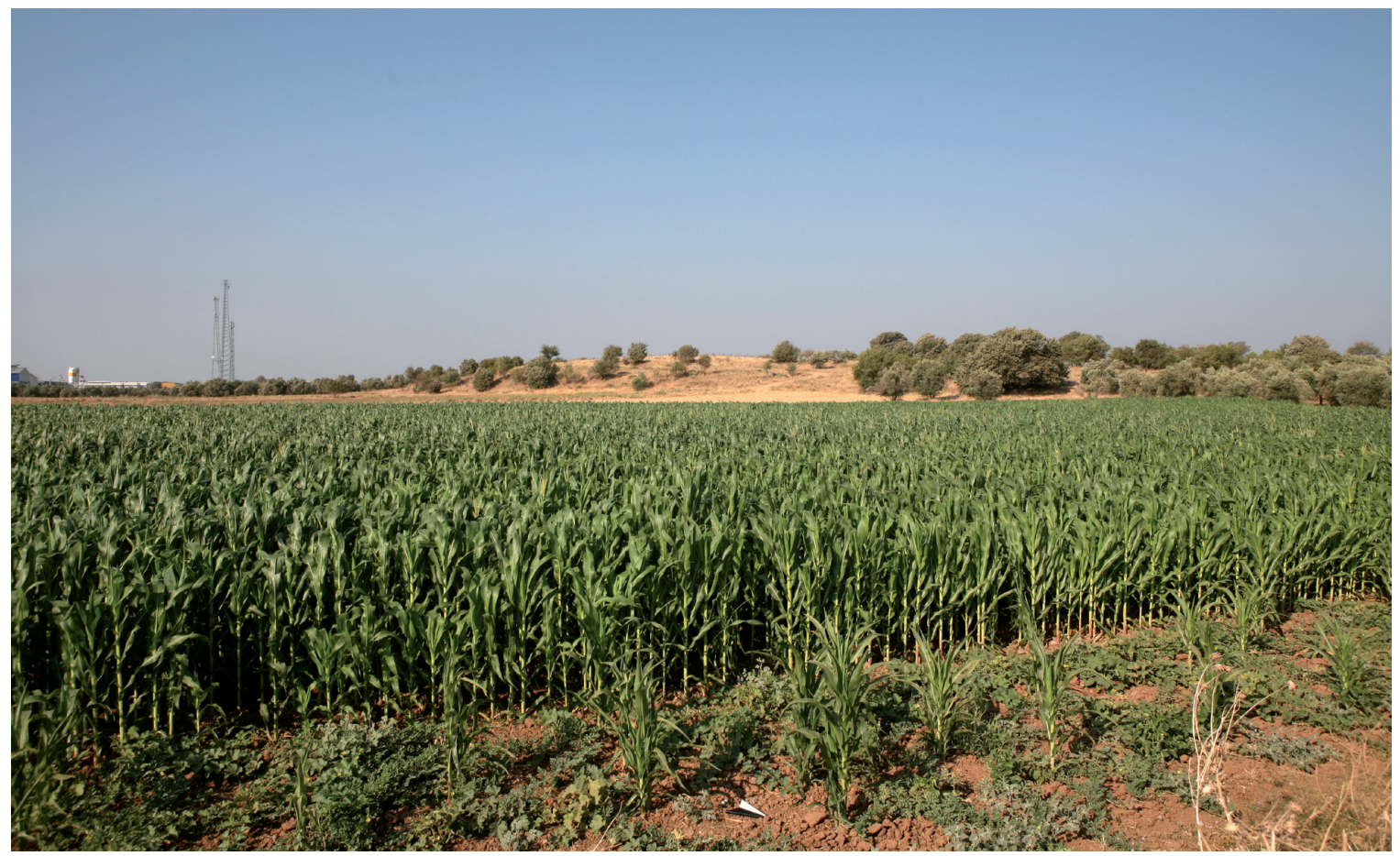

Fig. 13 Değirmentepe with view from northeast to southwest (Photo by Mario Börner/OREA)

tions could certainly have acted as impetus for a more widespread settling of the landscape. In any case, the rise in settlement density around 1700 $\mathrm{BCE}$, lasting at least two to three centuries, could be observed almost everywhere in Western Anatolia and cannot just be a coincidence.

Yet, what sets the Bakırçay Valley apart from the other settlement chambers of Northwestern Anatolia is a seeming lack of any major 'central place'. Admittedly, Değirmentepe yielded the most material and one could consider it a 'local central place' in the Lower Bakırçay Valley. The natural mound represents one of the largest tepes in the region in being 450 metres long (north-south) and 230 metres wide (east-west) (Fig. 13). Although the cultural layers are heavily eroded today, the surface collection of finds during our surveys demonstrate the use of the complete tepe in $2^{\text {nd }}$ millennium BCE. All of the intensive surveyed areas 1-11 revealed ceramics or other archaeological artefacts. While these remains might have been relocated, the geophysical investigations in area 1, the eastern part of the mound, demonstrate domestic remains in situ (Fig. 14). The interpretations of the geophysical results by Eastern Atlas (Berlin) let us assume few remains of rectangular and linear architecture, an accumulation of pits and pyrotechnical installations (ovens?) as well as the structure of a potential ditch following partially the outer edges of the tepe in north-south direction. It is certainly the only site which covers the whole period under study (with the exception of the final stage, however, which is nonetheless largely absent). This longevity of the site is a new information, since previously it was stressed that it is not a tell and the habitation layer is only $40 \mathrm{~cm}$ thick. ${ }^{68}$ Nevertheless, the lower valley is where developments seem to concentrate in the $2^{\text {nd }}$ millennium BCE, as almost all possible imports and unusual wares (e.g. Mycenaean, Schamotte and Creamy Ware) were all found there and are likely linked with activities of the settlements in the vicinity of the coast. What might have possibly come as a surprise was that the site of Pergamon, so dominant in the valley during the later periods, seems to have played a very small, and certainly not a central role in the prehistory of the valley. The geological and topographical setting of the acropolis seems very untypical for a prehistoric settlement; in MBA/LBA communities preferred settling in the plain or on small natural elevations or tells.

68 BAYNE 2000, 90. 


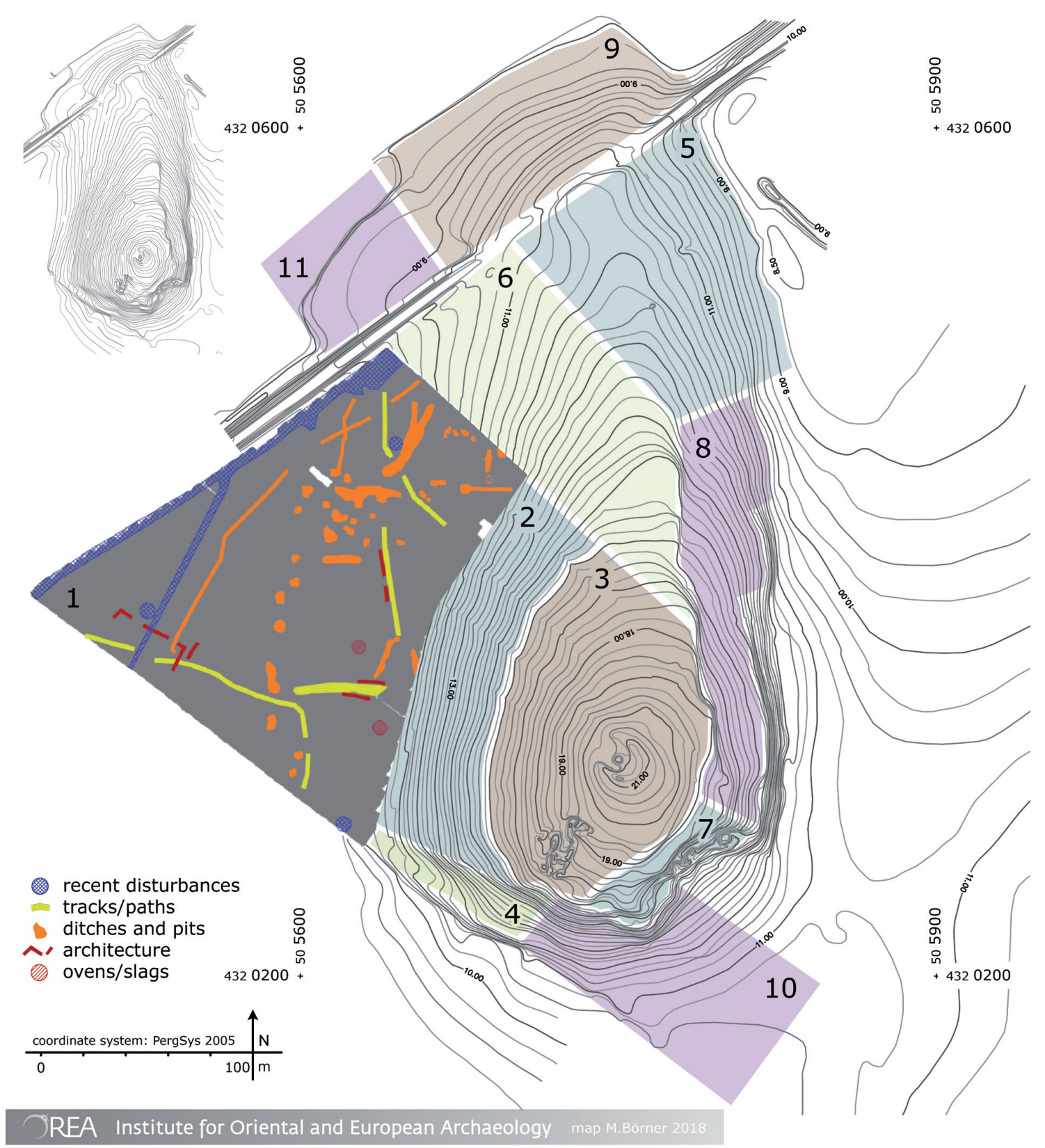

Fig. 14 Topographical map of Değirmentepe with areas 1-11 of intensive and systematic surface collections and interpreted results of geophysical investigations in area 1 by Eastern Atlas (Map by M. Börner/OREA).

\section{Other types of evidence}

Geoarchaeological investigations, including sedimentology, drillings, geophysics, geological, and raw material studies, revealed new data about the paleoenvironment, as well as the exploitation of natural resources in the region. ${ }^{69}$ The main results of these interdisciplinary studies for this regional approach lie in the seasonal accessibility of the landscape and its transit options as well as in past societies' sourcing strategies. The relatively wide open valley seems to have been flooded regularly,

69 See the annual reports in the Archäologischer Anzeiger until 2018; SCHLÖFFEL et al. 2017; SCHNEIDER et al. 2017; HOREJS 2014c. 
as attested by fluvial sediments at various locations. ${ }^{70}$ The meandering river still causes seasonal flooding even today, thus preventing an easy cross-valley transit. Before the modern river regulations and agricultural technologies, an impact can be therefore assumed on not only communication and transport routes, but also on agricultural and herding strategies. Bronze Age communities both in the centre (Yeni Yeldeğirmentepe) and along the edges of the Bakırçay Valley (Çiftlik, Değirmentepe) had to face the river's impact, including potential flooding of their living quarters. These environmental conditions might have influenced the development of continuously settled areas even at the natural mounds and might have, therefore, prevented the creation of larger central places.

The analyses of resources, artefacts, and tools have demonstrated an intensive knowledge and the use of the regional landscape by past societies. The various local sources of clay, volcanic rocks, neogene lacustrine silicites (cherts), jasper, and chalcedony were exploited and distributed within the valley. ${ }^{71}$ Based on these new primary data, we assume that the majority of raw material management was organised locally and distributed only on a micro-regional scale. One single obsidian import was identified at Bağlı Tepe, situated in the Gümüşova Valley. ${ }^{72}$ The lead isotope analyses of the two discovered metal implements (EBA needles) indicate the use of Western Anatolian copper deposits, but it is currently not possible to pinpoint their actual production area. ${ }^{73}$ Based on the survey results it can also be posited that everyday demands were met by local resources, and the more exotic materials, such as jadeite, obsidian, semi-precious or precious stones and metals, were either not accessible or not needed by the local communities. In any case, the data suggest that the prehistoric societies of the Bakırçay Valley were not active in inter-regional exchange networks, which is a quite different pattern compared to the raw material management strategies of the neighbouring regions in Western Anatolia.

\footnotetext{
to Seeliger et al. 2011; Schneider et al. 2017; SChlöFfel et al. 2017.

71 Horess and Schwall 2016; Horess et al. 2018; in press.

72 Horess et al. 2018; in press.

Mehofer 2014; Mehofer in preparation.

Published with some delay in PAvúK 2015.

Mellaart in Lloyd and Mellaart 1965.
}

\section{The bigger picture}

So how does the Bakırçay Valley fit into the bigger picture of Western Anatolian development? Because of the already mentioned lack of excavated sites and predominance of survey finds in the area, we have to focus on what we have at our disposal: the ceramics and the settlement patterns. This article is a welcome opportunity not only to present the new data, but also to re-asses some of the results presented by Peter Pavúk at the 'Nostoi' conference back in $2011,{ }^{74}$ which summarised the $2^{\text {nd }}$ millennium BCE ceramic groups in Western Anatolia (Fig. 15), based on the composition of ceramic assemblages.

Back then, it was postulated that within the Northwestern Anatolian ceramic province (already defined by J. Mellaart) ${ }^{75}$ there are two main ceramic groups: one in the Troad and another one stretching from the Balıkesir basin down to the İzmir area, and encompassing the regions lying inbetween. Having recognised a slight difference between the Balıkesir and the Akhisar-Manisa materials and not having properly handled the Bakırçay finds at that point, Peter Pavúk was inclined to include the Bakırçay Valley in one group with the Akhisar-Manisa region. This reconstruction now certainly needs an adjustment, since previously unrecognised links can now be distinguished between the Bakırçay and Balıkesir materials. In addition, the autopsy of the survey material collected by M. Özdoğan south of the Marmara $\mathrm{Sea}^{76}$ made clear that there is no separate Propontic ceramic group, but rather the Troad group extends as far as the site of Bardakçı below the Kapıdağ Peninsula. Here, around modern Bandirma, the pattern-burnished İnegöl group starts and continues towards the İznik Lake (Fig. 15).

The following adjustment to the originally-postulated ceramic grouping in Northwestern Anatolia can be made: there is one group in the north, covering not only the western but also the eastern part of the Troad (as defined by Strabo), ${ }^{77}$ possibly also including the Edremit plain, ${ }^{78}$ followed by a

\footnotetext{
76 ÖZDOĞAN 1991; 1993; to be published by A. Schachner (forthcoming). P. Pavúk would like to thank M. Özdoğan for the permission to see the finds.

77 PAvÚK and Schubert 2014.

78 Observed also by BAYNe 2000, 61.
} 


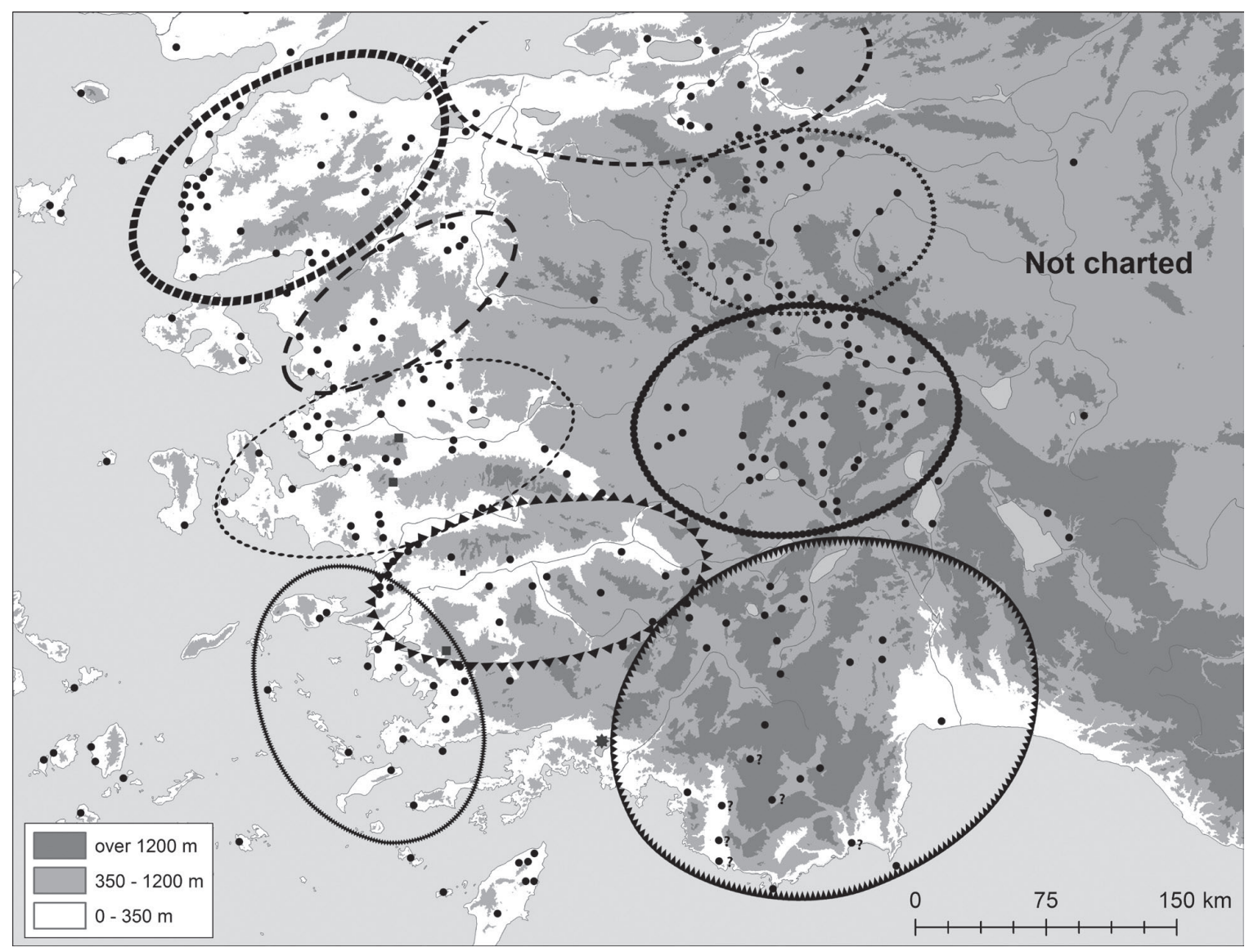

Fig. 15 Western Anatolian LBA ceramic groups, current state-of-the-art in 2018 (Map by P. Demján and A. Kapcár)

second group including the Bakırçay Valley and the Balikesir basin, and finally, a third group in the Akhisar-Manisa plain, including parts of the Gediz Valley. However, the Urla peninsula (with its many sites) and the Küçük Menderes/Kaystros Valley to the south also yielded LB 1 Anatolian Grey Ware, and should thus in theory be part of the same Northwestern Anatolian province. What possibly sets them apart is the red and beige spectrum of the ceramic production, interlinked more with the southeast of Anatolia.

Attempting to draw such specific borders between ceramic groups feels too rigid and the Bronze Age reality was likely more fluid with overlapping zones, at least certainly in Western Anatolia. Through a bottom-up approach, each settlement chamber/valley/basin can be considered

79 In the Troad, there are, for example, two major production centres, one at Troy and one in the southern Troas (possibly at Larissa-Liman Tepe), which supplied two different circuit parts of the Troas, but showed a roughly similar set of shapes and wares (PAVÚK and SCHUBERT 2014). a zone on its own right, with a relatively unified pottery profile, and allowing for the existence of multiple workshops. ${ }^{79}$ However, in order to see the forest and not just the individual trees, one attempts to group these smaller units into larger ones, similar to a dendrogram. But even this exercise is not easy, as the individual trees comprise mostly survey-sites, and the evidence cannot be properly quantified. Thus, even if one is tempted to draw clear-cut borders between the ceramic groups on the map,$^{80}$ the reality was more complex. What we need is a polythetic approach, which weights different variables at different points of the analysis.

To provide further explanation, it should be noted that the coastal sites complicate such groupings, as they are more influenced by the Aegean ele-

80 Cf. SARI 2013 for trying to provide more specific borders in
this respect. 
ments coming across the sea, but, at the same time, they also reflect the material culture of their Anatolian hinterland. Interestingly, the Aegean elements do not penetrate further inland. The question then is: by how much does this Aegean influence set the coastal settlements apart from their inland contemporaries, even within the same valley?

The picture differs depending on the wares that we look at. Distribution of the Grey Wares and the shapes therein shows a certain pattern, the Gold Wash Ware, and Buff and Reddish Wares offer in turn a different one. Whereas the wares (and mostly also shapes) are more alike in the northern groups (Troad, Balıkesir, Bakırçay), the southern groups (the Büyük Menderes/Meander Valley with its tributaries) are kind of intermediates between the northwestern ceramic province (with predominantly Grey Wares) and the southwestern ceramic province, where there is no Grey Ware and redlight brown and Gold Wash fabrics and wares predominate. This intermediate ceramic province would include the İzmir region, the Akhisar-Manisa plain, the Marmara Lake basin, and the Küçük Menderes Valley.

Changes over time enter yet another dimension into our reconstructions, as the locally produced Grey Wares seem to lose popularity over time. Whereas their decrease during LB 2 is relatively minor in the north (Troad, Balıkesir, Bakırçay), it is much more dramatic in the south. While the Grey Ware seems to remain relatively popular in the coastal sites in the İzmir region during LB $2,{ }^{81}$ further inland in the Gediz Valley its ratio to buff and other light-faced fabric is not as high as in the north. ${ }^{82}$ And even when Grey Wares survive in this area, they lose the burnishing in contrast to the north. Going beyond a positivistic description, one has to wonder what this change from the popularity of grey to reddish and beige ceramic style means and how much of it is linked with changes in firing technology. Thus, this change should be considered a defining criterion as well.

\section{Connectivity}

In terms of connectivity, the Bakırçay Valley consists of three parts - the upper, middle and lower

\footnotetext{
81 Cf. all the Grey Ware vessels in the Panaztepe cemetery, some of which have Mycenaean shapes (Günel 1999a).

82 Cf. the new data from Kaymakçı: Roosevelt et al. 2018.

83 Kâmil 1982; Bittel 1955, 113-118; Akurgal 1958; KorfMANN 2005.
}

valley - which certainly communicated along the river. This general observation is also underpinned by the results of the ceramic analyses by means of NAA (conducted by S. Japp and H. Mommsen), which showed the existence of different pottery production centres in the upper, central, and lower valley and exchange between them. More specifically, imports from the lower valley were found in the upper valley, but the upper valley certainly easily communicated with the east as well through the valleys around Soma. The routes led to either the Akhisar plain (roughly following the modern railway system) or the northeast towards the Balıkesir basin. These communication routes must have been established long before, since the known EBA cemeteries of Yortan and Ovabayındır are located just east of Soma. ${ }^{83}$ Later on, this situation is mirrored by the Hellenistic road system leading out of the valley across Soma down to Akhisar, and likely also along Kaymakçı to Sardis ${ }^{84}$ The central part of the Bakırçay Valley seems to have communicated not only with the lower part of the valley, but also across the mountains to the south of it, through suitable passes, as suggested by the presence of a single import from Gavur Evleri located on the coast.

The lower Bakırçay Valley is relatively flat and likely enjoyed a criss-cross-like communication between various sites (supported by the NAA results and the higher occurrence of imported/ 'unusual' wares), complemented by routes along the coast, be it to the north and the Edremit region (itself a small settlement chamber, almost completely blocked out from any neighbouring region by steep mountains on its north and east), or to the south, toward the classical Kyme and Phocaea, sides. Possible contact with Lesbos is a chapter on its own right, as the island is situated right in front of the Bakırçay estuary. The contemporary material from the main site on Lesbos' east coast, Thermi, included some Anatolian shapes and wares (e.g. Red Washed and Grey Wares), ${ }^{85}$ but chemical analyses are needed in order to establish whether these were imported or not. The new excavations by Olga Philaniotou yielded considerable amounts of Grey Ware (not matched by the old finds from the Lamb excavations), which will

\footnotetext{
84 VAessen 2017, Fig. 2.

85 Lamb 1936, Fig. 39, 2-4, Fig. 40, 2-11; Bayne 2000, 94-101, Fig. 25, 26: 7-8.
} 
likely change the picture of current knowledge, but results need to be published first. ${ }^{86}$

However, despite all these possibilities for communication and contact partly enabled by its coastal position, the Bakırçay Valley remained a bit of a back-water not only in the $2^{\text {nd }}$ millennium BCE, but also throughout prehistory. ${ }^{87}$ The absence of any really major central place might fit this picture not only in the $2^{\text {nd }}$ millennium $\mathrm{BCE}$, but also in the preceding millennia. This is especially interesting when one considers that coastal Thermi on Lesbos shows a strong development leading to a proto-urban centre already in EB 1 and EB 2. There is no comparable trend in the Bakırçay Valley; however, one must also admit that none of the sites in the valley have so far been excavated.

\section{Conclusions}

The aim of this article was to fill-in a relatively blank space on the cultural map of the $2^{\text {nd }}$ millennium BCE Western Anatolia. Perhaps it was not a completely white spot, since there was some previous knowledge, but certainly a grey, rather than a colourful, one. The best-known site remained Değirmentepe, but we are now much better equipped to place it against its local background. More sites with $2^{\text {nd }}$ millennium BCE pottery have been recovered when compared to what was known to J. Driehaus in 1957, and thanks to the better understanding of the ceramic sequence at Troy, one can now get a better grasp on the developments in the Bakırçay Valley.

By analysing the main source of information at hand - the pottery - a development from final EB 3 through MB, LB 1, and LB 2 up to the transition into EIA was sketched, wares were defined, and shapes were tabulated. Deriving from these three pillars, a general habitation trend has been deduced as follows. There were a few sites in MBA, almost all recorded sites were settled in LB 1, but there was a slight decrease in settlement density in LB 2, followed by a further decrease to only two sites in EIA. The predominant ware in

${ }^{86}$ Here P. Pavúk would like to thank O. Philaniotou for the kind permission to briefly see the material in 2010. See now Philaniotou 2018.

87 For the other periods, see HoREJs 2014c.

88 For the Madra Çay delta area situated south of Edremit plain, see BAYNE and SPENCER 2007, which is mostly based on Bayne's PhD dissertation from 1963. the LBA is the local Grey Ware complemented by small percentages of other local wares. Employment of preliminary NAA results shows an interesting exchange network in the lower Bakırçay Valley and between the lower and upper parts of the valley as well as a supply of pottery in the central part of the valley from both the upper and lower valley sites. A new Mycenaean kylix fragment was presented from Atarneus, and an additional kylix fragment was identified from Elaia.

Using the local wares, it was shown how the development in the Bakırçay Valley matches that of the neighbouring Edremit plane, ${ }^{88}$ the Troad, ${ }^{89}$ and the Balıkesir basin. ${ }^{90}$ Contrary to previous suggestions, it was shown that the continued high popularity of Grey Ware in LB 2 and the continued use of burnishing sets Bakırçay Valley apart from its southern neighbours in the Akhisar-Manisa plane and in the Gediz and Küçük Menderes Valleys.

When comparing Bakırçay Valley with the Troad, the İzmir region, and the Selçuk area, one cannot fail to notice the more 'rural' character of the area. In the material culture, this is best demonstrated by the absence of various types of imports, especially the Mycenaean Decorated Ware, as has already been pointed out elsewhere. ${ }^{91}$ While the area is still under-researched compared to the other three above-mentioned areas (with no properly excavated prehistoric site), it cannot be a complete coincidence that there are barely any Mycenaean or other imports known, especially as they are known in modest numbers from nearby Lesbos. One possible explanation can be the absence of long-distance route leading to the Central Anatolian Plateau (not only in LBA, but throughout prehistory). While such routes can be argued to have been present along the southern coast of the Marmara Sea or in the valley of rivers Gediz and Büyük Menderes, this does not hold in case of the Bakırçay Valley. ${ }^{92}$ We believe that it is not a coincidence that the valley was tucked away from the main happenings of the period. These conclusions about MBA and LBA from the new surveys can be embedded in a longue durée pic-

\footnotetext{
Pavúk and Schubert 2015.

FRENCH 1969.

Mee 1978; Mountjoy 1998; Kelder 2006.

92 PAVúk 2015, Fig. 6; VAessen 2017,70-71, Fig. 2.
} 
ture of the region, characterised by its own manners of adoption of new trends, technologies, and raw materials from the other parts of this larger region. Finally, this 'backwater' aspect of the Bakırçay Valley inevitably leads to the conclusion that it could not have been a centre of the Šeha River Land mentioned in the Hittite sources, as had been argued previously. ${ }^{93}$ The latter one is more likely to be situated in the nearby Gediz Valley. ${ }^{94}$

Returning back to the thoughts expressed in the introductory paragraphs: can we now answer the question to what degree do developments in Western Anatolia, with the state of knowledge in the year 2018, match the developments on the Greek Mainland, on the one hand, and Central Anatolia, on the other hand? As patchy as the evidence remains, we see more and more that Western Anatolia was not just a poorer cousin of its better-known neighbours and that its material culture did not just mirror or imitate. We can certainly conclude that many of the processes observed specifically in Mainland Greece in the $2^{\text {nd }}$ millennium $\mathrm{BCE}$ can be traced (to various degrees) also in Western Anatolia. ${ }^{95}$ While this is not the place for a full discussion of all such aspects, one can by now conclude that there is both a diversity (in terms of various cultural groups from north to south) and similarity (in terms of ways of doing things). While we see a surprisingly cosmopolitan society along the coast, absorbing Aegean impeti and mingling them with the local tastes (exemplified by Troy in the north and all the coastal sites south of Panaztepe), ${ }^{96}$ a higher degree of conservative traditions persist further inland. What we witness in the entire region, however, are various strategies to negotiate group identities and a much more active approach to influences from other regions. ${ }^{97}$

Finally, from a more disciplinary perspective, we now witness an important shift in the way Late Bronze Western Anatolia is conceptualised in scholarship. While the coastal communities are no longer perceived as passively accepting Aegean stimuli, these and inland communities are no longer defined through the manner in which they interacted with the Mycenaeans or the Hittites. ${ }^{98}$ And looking at the Western Anatolian communities on its own terms is the way forward to the future.
93 Jewell 1974, Map. 25; Hawkins 1989; Latacz and Starke 2006.

94 As recently tentatively also suggested by Roosevelt and LUKE 2017.

95 Pienią̇̇eK and PAVÚK 2016.
VAESSEN 2016; 2017.

97 Mac Sweeney 2009; 2011.

98 Girella and Pavúk 2015; Mac Sweeney 2010; Mokrišová 2015. 


\section{Bibliography}

AkArCA, A.

1978 Troas’ta aşağı Kara Menderes ovası cevresindekı şehirler, Belleten XLII (165), 1-52.

Akdeniz, E.

2006 A New Excavation in Western Anatolia: Kadıkalesi (Ancient Anaia), Olba XIII, 1-33.

2007 Kadıkalesi Kazısı Miken Buluntuları, Arkeoloji Dergisi 9 (1), 35-70.

Akurgal, E.

1950 Bayraklı Kazısı Ön Rapor - Bayraklı: Erster vorläufiger Bericht über die Ausgrabungen in Alt-Smyrna, Dil Tarih Cografya Fakültesi Dergisi VIII (1), 1-51.

1958 Yortankultur-Siedlung in Ovabayındır bei Balıkesir, Anadolu 3, 156-164.

Aslan, R., Bieg, G., Jablonka, P. and Kronneck, P.

2003 Die mittel- bis spätbronzezeitliche Besiedlung (Troia VI und Troia VIIa) der Troas und der Gelibolu-Halbinsel. Ein Überblick, Studia Troica 13, 165-213.

Aykurt, A.

2006 Kocabaş Tepe seramik firını, 113-119, in: A. ERKANAL-ÖКтÜ et al. (eds.), Hayat Erkanal'a armağan. Kulturlerin yansimass $=$ Studies in Honor of Hayat Erkanal, Cultural Reflections, Ankara.

BAYNE, N.P.

1963 The Grey Wares of Northwest Anatolia in the Middle and Late Bronze Age and Early Iron Age and their Relation to the Early Greek Settlements, PhD. Dissertation, University of Oxford.

2000 The Grey Wares of Northwest Anatolia in the Middle and Late Bronze Age and Early Iron Age and their Relation to the Early Greek Settlements, Asia Minor Studien 37, Bonn.

Bayne, N. P. and SPEncer, N.

2007 The ceramics of the northeast Aegean region from the Middle Bronze Age to the Early Iron Age, 79-89, in: K. LAmbrianides and N. Spencer: The Madra River Delta: Regional Studies on the Aegean Coast of Turkey. Vol. 1: Environment, Society and Community Life from Prehistory to the Present, The British Institute at Ankara Monograph 35, Ankara.

Bittel, K.

1950 Zur ältesten Besiedlungsgeschichte der unteren Kaikosebene, Istanbuler Forschungen 17, 10-29.

Blegen, C. W., Caskey, J.L. and Rawson, M.

1950 Troy I. General Instroduction. The First and Second Settlements, Princeton.

1951 Troy II. The Third, Fourth and Fifth Settlements, Princeton.

1953 Troy III. The Sixth Settlement, Princeton.

Blegen, C. W., Boulter, C.G., Caskey, J.L. and Rawson, M.

1958 Troy IV. Settlements VIIa, VIIb and VIII, Princeton.
Boehlau, J. and Schefold, K.

1942 Larisa am Hermos. Die Ergebnisse der Ausgrabungen 1902-1934 III. Die Kleinfunde, Berlin.

Boysal, Y.

1967 Müskebi kazısı 1963 kısa rapörü. Vorläufiger Bericht über die Grabungen 1963 in Müskebi, Belleten 31, 67-83.

Bozhinova, E., Jung, R. and Mommsen, H.

2010 Dragojna: Eine spätbronzezeitliche Höhensiedlung in den bulgarischen Rhodopen mit importierter mykenischer Keramik, $A M$ 125, 45-97.

Broodbank, C.

2004 Minoanisation, PCPS 50, 46-91.

BRYCE, T.

2011 The Late Bronze Age in the West and the Aegean, 363-375, in: S.R. StEAdMAn and G. McMahon (eds.), The Oxford Handbook of Ancient Anatolia, 10,000323 B.C.E., Oxford.

BÜYÜKKOLANCI, M.

2007 Apaša, das alte Ephesos und Ayasoluk, 21-26, in: CoBet et al. (eds.) 2007.

Choleva, $\mathrm{M}$.

2012 The First Wheelmade Pottery at Lerna: WheelThrown or Wheel-Fashioned? Hesperia 81 (3), 343381.

CoвB, P.J.

2016 Computational Analyses of Archaeological Ceramics: The Second Millennium BCE Ceramics of the Marmara Lake Basin in their Western Anatolian Regional Context. PhD. Dissertation, University of Pennsylvania.

Cobet, J., von Graeve, V., Niemeier, W.-D. and Zimmermann, M. (eds.)

2007 Frühes Ionien: eine Bestandsaufnahme. PanionionSymposion Güzelcaml, 26. September - 1. Oktober 1999, Milesische Forschungen 5. Mainz.

Collins, B.J., Bachvarova M.R. and Rutherford, I.C. (eds.)

2008 Anatolian Interfaces: Hittites, Greeks and Their Neighbours. Proceedings of an International Conference on Cross-Cultural Interaction, September 17-19, 2004, Emory University, Atlanta, GA, Oxford.

CoOK, J.M.

1973 Bronze Age Sites in the Troad, 37-40, in: R.A. CrossLAND and A. Birchall (eds.), Bronze Age Migrations in the Aegean. Archaeological and linguistic problems in the Greek prehistory, London.

ÇAYMAZ, T.

2008 Urla Yarımadası Prehistorik Yerleşimleri, Arkeoloji Dergisi 11 (1),1-41. 
Çinardali-KaraAslan, N.

2008 Recent Investigations at Panaztepe Harbour Town, 69-90, in: A. ERkanal-Öктü, S. Günel and U. Deniz (eds.), Batı Anadolu ve Doğu Akdeniz Geç Tunç Çağ1 Kulturleri Uzerine Yeni Araştirmalar, Ankara.

DedeoĞLu, F. and ABAy, E.

2014 Beycesultan Höyük Excavation Project: New Archaeological Evidence from Late Bronze Layers, Arkeoloji Dergisi 19, 1-39.

DedeoĞLu, F. and KonaKçı, E.

2015 Local painted pottery tradition from inland southwest Anatolia and its contribution to second millennium B.C. chronology. Mediterranean archaeology and archaeometry 15 (2), 191-214.

DÖRPFELD, W.

1908 Ausgrabungen in Pergamon, Technisches und Architekturtagebuch Pergamon 1908, 16-23.

Dörpfeld, W. and Hepding, H.

1910 Die Arbeiten zu Pergamon 1908-1909, AM 35, 345526.

Driehaus, J.

1957 Prähistorische Siedlungsfunde in der unteren Kaikosebene und an dem Golfe von Çandarlı, IstMitt 7, 76-101.

EDER, B.

2009 The northern frontier of the Mycenaean world, 113-

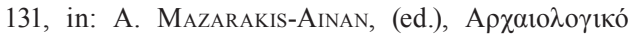

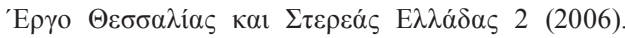

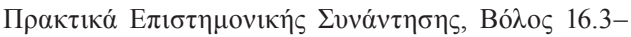
19.3.2006, Volume I: $\Theta \varepsilon \sigma \sigma \alpha \lambda i \alpha$, Volos.

EDER, B. and JuNG, R.

2015 'Unus pro omnibus, omnes pro uno': The Mycenaean Palace System, 113-140, in: J. Weilhartner and F. RuPPENSTEIN (eds.), Tradition and Innovation in the Mycenaean Palatial Polities, Österreichische Akademie der Wissenschaften Philosophisch-Historische Klasse Denkschriften 487, Mykenische Studien 34, Vienna.

EFE, T.

1994 Early Bronze Age III Pottery from Bahcehisar. The Significance of the Pre-Hittite Sequence in the Eskişehir Plain, Northwestern Anatolia, AJA 98 (1), $5-34$.

ERKANAL, $\mathrm{H}$.

2008 Geç Tunç Cağı'nda Liman Tepe, 91-100, in: A. ERKAnaL-Öктü, S. Günel and U. DenIz (eds.), Batı Anadolu ve Doğu Akdeniz Geç Tunç Çağ Yeni Araştirmalar, Ankara.

ERKANAL-ÖKtü, A.

2008 The Late Bronze Age Cemeteries of Panaztepe, 69-90, in: A. Erkanal-Öкtü, S. Günel and U. Deniz (eds.), Batı Anadolu ve Doğu Akdeniz Geç Tunç Çağ Kulturleri Uzerine Yeni Araştirmalar, Ankara.
FRENCH, D.H

1967 Prehistoric Sites in Northwest Anatolia I: The İznik Area, AnatSt 17, 49-100.

1969 Prehistoric Sites in Northwest Anatolia II: The Balıkesir and Akhisar/Manisa Areas, AnatSt 19, 41-98.

1973 Migrations and 'Minyan' Pottery in Western Anatolia and the Aegean, 51-54 in: R.A. Crossland and A. Birchal (eds.), Bronze Age Migrations in the Aegean. Archaeological and linguistic problems in Greek prehistory, London.

Gimatzidis, S., Pieniążek, M. and Mangaloğlu-Votruba, S. (eds.)

2018 Archaeology across Frontiers and Borderlands. Fragmentation and Connectivity in the North Aegean and the Central Balkans from the Bronze Age to the Iron Age, Wien 2018.

Glatz C.

2009 Empire as Network: Spheres of Material Interaction in Late Bronze Age Anatolia, JAnthArch 28, 127-141.

Gorogianni, E., Pavúk, P. and Girella, L.

2016 Beyond Thalassocracies: Understanding Processes of Minoanisation and Mycenaeanisation in the Aegean, Oxford and Philadelphia.

Grave, P., Kealhofer, L., Hnila, P., Marsh, B., Aslan, C., Thumm-DoĞrayan, D. and Rigter, W.

2013 Cultural Dynamics and Ceramic Resource Use at Late Bronze Age/Early Iron Age Troy, Northwestern Turkey, Journal of Archaeological Science 40 (4), 17601777.

Greaves, A.M.

2010 Western Anatolia, 877-889, in: E.H. Cline (ed.), The Oxford Handbook of the Bronze Age Aegean (ca. 3000-1000 BC), Oxford.

GÜNEL, S.

1999a Panaztepe II. Die Keramik von Panaztepe und ihre Bedeutung für Westkleinasien und die Ägäis im 2. Jahrtausend, Turk Tarih Kurumu Yayınlarından VI-51, Ankara.

1999b Vorbericht über die mittel- und spätbronzezeitliche Keramik von Liman Tepe, IstMitt 49, 41-82.

2003 Vorbericht über die Oberflächenbegehungen in den Provinzen Aydın und Muğla, Anatolia antiqua. Eski Anadolu 11, 75-100.

2004 Aydin Bölgesi Yüzey Arastirmalari: Erken Dönem Yerlesmeleri ve Buluntulari Isiginda Kültürel Gelisi$m i$, 95-114, in: Z. Cizzmeli-ÖĞÜN, L. KesKin, T. ŞıPAHI (eds.), I-II Ulusal Arkeolojik Arastirmalar Sempozyu$m u$, Anadolu/Anatolia, Supplement Series 1. Ankara.

2005 The cultural structure of Aydin-Ikizdere region in the prehistoric age and its contribution to the archaeology of Aegean Region, Anatolia Antiqua 13, 29-40. 
2006 New Contributions to Western Anatolian Cultural History. Aydın Region Survey Project, PZ 81, 153 174.

2010 Mycenaean Cultural Impact on the Cine (Marsyas) Plain, Southwest Anatolia: The Evidence from CineTepecik, AnatSt 60, 25-49.

2015 Çine-Tepecik: New Contributions on Late Bronze Age Cultures in Western Anatolia, 627-646, in: StAmPoLIDIS et al. 2015.

Hanfmann, G. M. A.

1967 The ninth campaign at Sardis (1966). Bulletin of the American Schools of Oriental Research 186, 17-53

Hawkins, J.D.

1998 Tarkasnawa King of Mira: 'Tarkondemos', Bogazkoy Sealings and Karabel, AnatSt 48, 1-31.

Hertel, D.

2011 Das vorklassische Pergamon und sein Siedlungsprofil, IstMitt 61, 21-84.

HNILA, P.

2012 Pottery of Troy VIIb. Chronology, classification, context and implications of Trojan ceramic assemblages in the Late Bronze Age/Early Iron Age transition. $\mathrm{PhD}$. Dissertation, Tübingen.

http://hdl.handle.net/10900/46997

Horess, B.

2007 Das prähistorische Olynth. Ausgrabungen in der Toumba Agios Mamas 1994-1996. Die spätbronzezeitliche handgemachte Keramik der Schichten 13 bis 1. Prähistorische Archäologie in Südosteuropa 21, Rahden.

2009 Yeni Yeldeğirmentepe, in: F. PIrson, Pergamon - Bericht über die Arbeiten in der Kampagne 2008, $A A$ 2009 (2), 168-174.

2010a Bronzezeitliche Besiedlungsmuster im Kaikostal. Interpretationen erster Surveyergebnisse im Umland von Pergamon (Türkei), 47-67, in: B. Horess and T. Kientin (eds.), Siedlung und Handwerk. Studien zu sozialen Kontexten in der Bronzezeit, Universitätsforschungen zur Prähistorischen Archäologie 194, Bonn.

2010b Yeni Yeldeğirmentepe, in: F. PIRson, Pergamon - Bericht über die Arbeiten in der Kampagne 2010, $A A$ 2010 (2), 164-168.

2010c Possibilities and Limitations in Analysing Ceramic Wares, 15-27, in: B. Horejs, R. Jung and P. PAvúK (eds.), Analysing Pottery. Processing, Classification, Publication, Bratislava.

2011a Prähistorische Surveys am Yeni Yeldeğirmentepe und im Umland von Pergamon, in: F. Pirson, Pergamon Bericht über die Arbeiten in der Kampagne 2010, AA 2011 (2), 146-150.

2011b Bergama and the Bakurçay Valley in Prehistory, 24-36, in: E. ÖNEN, M. MutLuer and N. ÇEtin (eds.),
Proceedings of the International Bergama Symposium, 7.-9. April 2011, Bergama.

2012 Der prähistorische Umlandsurvey, in: F. PIRson, Pergamon - Bericht über die Arbeiten der Kampagne 2011, AA 2012 (2), 204-208.

2013 Der prähistorische Umlandsurvey, in: F. PIRson, Pergamon - Bericht über die Arbeiten in der Kampagne 2012, AA 2013 (2), 109-117.

2014a The 2nd millennium BC in the Baktrcay (Kaikos) Valley. An overview, 257-274, in: N. ÇinardaliKaraaslan, A. Aykurt, N. Kolankaya-Bostanci and Y. H. Erbil (eds.), Anadolu Kültürlerine Bir Bakış. Armağan Erkanal'a Armağan / Some Observation on Anatolian Cultures. Compiled in Honor of Armağan Erkanal, Ankara.

2014b Der prähistorische Umlandsurvey, in: F. PIRson, Pergamon - Bericht über die Arbeiten in der Kampagne 2013, AA 2014 (2), 141-146.

2014c Pergamon and the Kaikos Valley in Prehistoric Times, 106-119, in: F. Pirson and A. Scholl (eds.), Pergamon: Anadolu 'da Bir Helenistik Dönem Başkenti. Pergamon: A Hellenistic Capital in Anatolia, Istanbul.

Horejs, B. and Schwall, $\mathrm{CH}$.

2016 Das Umland von Pergamon, 170-172, in: F. PIRson (ed.), Pergamon. Bericht über die Arbeiten in der Kampagne 2014, Archäologischer Anzeiger 2016 (2).

HoRejs et al. 2015

Horejs, B., Milić, B. and Pavúk, P.

2015 Das prähistorische Umlandsurvey, 134-139, in: F. PIRSON (ed.), Pergamon. Bericht über die Arbeiten in der Kampagne 2014, Archäologischer Anzeiger 2015 (2).

Horess, B. et al. 2018

Horejs, B., JApp, S. and Mommsen, H.

2018 EBA Pottery Workshops around Pergamon. A model for pottery production in $3 r d$ millennium $B C$, in: E. Alram and B. Horess (eds.), Pottery Technologies and Sociocultural Connections between the Aegean and Anatolia during the $3 r d$ millennium BC. Oriental and European Archaeology 10. Vienna, 25-61

Horejs, B. et al. in press

Horejs, B., Schwall, Ch., Milić, B. and Brandl, M.

In press Der prähistorische Umlandsurvey, in: F. PIRson, Pergamon - Bericht über die Arbeiten in der Kampagne 2017, AA 2018 (2), in press.

JEWELL, E.R.

1974 The Archaeology and History of Western Anatolia during the Second Millennium BC. Unpubl. Ph. D. diss., University of Pennsylvania, UMI 75-14574. Ann Arbor. 
JOUKOWSKY, M.S.

1986 Prehistoric Aphrodisias, an Account of the Excavations and Artifact Studies I, Archaeologia Transatlantica III. Providence and Louvain-la-Neuve.

KADISH, B.

1969 Excavations of Prehistoric Remains at Aphrodisias, 1967, AJA 73 (1), 49-65.

1971 Excavations of Prehistoric Remains at Aphrodisias, 1968 and 1969, AJA 75 (2), 121-140.

KÂMIL, T.

1982 Yortan cemetery in the early bronze age of Western Anatolia, BAR int. series 145, Oxford.

KeLDER, J.

2006 Mycenaeans in Western Anatolia. Talanta XXXVIXXXVII (2004-2005), 49-88.

KibaroĞLu, M. and Thumm-DoĞrayan, D.

2013 Trojan Pithoi: A Petrographic Approach to Provenance and Production Technique of Bronze Age Storage Vessels from Troy, Journal of Applied Clay Science $82,44-52$.

Korfmann, M.O.

2005 Ovabayındır, 150, in: Reallexikon der Assyriologie und Vorderasiatischen Archäologie 10: OannesPriesterverkleidung, Berlin.

Korfmann, M.O. ed.

2006 Troia. Archäologie eines Siedlungshügels und seiner Landschaft. Mainz.

LAMB, W.

1936 Excavations at Thermi on Lesbos, Cambridge.

Latacz, J. and Starke, F.

2006 Wilusa und die Großen Vier - Troia in der politischen Landschaft der späten Bronzezeit, 57-70, in: M.O. Korfmann (ed.), Troia. Archäologie eines Siedlungshügels und seiner Landschaft, Mainz.

LLOYD, S.

1972 Beycesultan. Volume III, Part I. Late Bronze Age Architecture. Occasional publications of the British Institute of Archaeology at Ankara 11, London.

Lloyd, S. and Mellaart, J.

1962 Beycesultan, Vol. I, The Chalcolithic and Early Bronze Age Levels, Occasional Publications of the British Institute of Archaeology at Ankara 6, London.

1965 Beycesultan, Vol. II, Middle Bronze Age Architecture and Pottery, Occasional Publications of the British Institute of Archaeology at Ankara 8, London.

LoHMAnN, H.

2004 Milet und die Milesia Eine antike Großstadt und ihr Umland im Wandel der Zeiten, 235-360, in: F. KolB and E. M. Luckner (eds.), Chora und Polis, München.

Luke, C., Roosevelt, C.H., CobB, P.J. and ÇilingiroĞLu, Ç.

2015 Composing communities: Chalcolithic through Iron Age survey ceramics in the Marmara Lake basin, western Turkey, Journal of Field Archaeology 40 (4), $428-449$.

Mac Sweeney, N.

2009 Beyond Ethnicity: The Overlooked Diversity of Group Identities, JMA 22 (1), 101-126.

2010 Hittites and Arzawans: a view from western Anatolia, AnatSt 60, 7-24.

2011 Community Identity and Archaeology. Dynamic Communities at Aphrodisias and Beycesultan. Ann Arbor.

MARAN, J.

2011 Lost in Translation: the Emergence of Mycenaean Culture as a Phenomenon of Glocalization, 282-293, in: T.C. Wilkinson, S. Sherratt and J. Bennet (eds.), Interweaving Worlds: Systemic Interactions in Eurasia, 7th to 1st Millennia BC, Oxford and Oakville.

MARChESE, R.

1976 Report on the West Acropolis excavations at Aphrodisias. 1971-1973, AJA 80 (4), 393-412.

1978 Late Mycenaean Ceramic Finds in the Lower Maeander River Valley and a Catalogue of Late Bronze Age Painted Motifs from Aphrodisias. The Archaeological Journal 135, 15-31.

Mee, $\mathrm{CH}$.

1978 Aegean Trade and Settlement in Anatolia in the Second Millennium B.C., AnatSt 28, 121-155.

Mehofer, M.

2014 Metallurgy of the Chalcolithic and the Beginning of the Early Bronze Age in Western Anatolia, in: B. Horess and M. Mehofer (eds.), Western Anatolia before Troy. Proto-Urbanisation in the 4th Millennium BC?, Oriental and European Archaeology 1, Vienna, 463-487.

in preparation Die Anfänge der Metallurgie in Westkleinasien. Spätchalkolithische und frühbronzezeitliche Metallverarbeitung auf dem Çukuriçi Höyük, Oriental and European Archaeology Series (Vienna, in preparation)

MellaArt, J.

1954 Preliminary Report on a Survey of Pre-Classical Remains in Southern Turkey, AnatSt 4, 175-240.

1955 Some Prehistoric Sites in North-Western Anatolia, IstMitt 6, 53-88.

1968 Anatolian Trade with Europe and Anatolian Geography and Culture Provinces in the Late Bronze Age, AnatSt 18, 187-202.

Mellaart, J. and Murray, A.

1995 Beycesultan III 2. Late Bronze Age and Phrygian Pottery and Middle and Late Bronze Age Small Objects. Occasional Publications of the British Institute of Archaeology at Ankara 12, London.

Meriç, R.

19891987 Yılı Alaşehir Kazısı, Kazı Sonuçları Toplantısı 10 (1), 157-170. 
19901988 Yılı Alaşehir Kazısı, Kazı Sonuçları Toplantısı 11 (1), 179-190.

19921990 Yılı Alaşehir Kazısı, Kazı Sonuçları Toplantısı 13 (2), 227-235.

2003 Excavations at Bademgediği Tepe (Puranda) 19992002: A Preliminary Report, IstMitt 53, 79-98.

2004 Metropolis: City of the Mother Goddess, Izmir.

2007 Ein Vorbericht über eine spätbronzezeitliche befestigte Höhensiedlung bei Metropolis in Ionien: Die Arzawa-Stadt Puranda?, 27-36, in: COBET et al. (eds.) 2007.

2009 Das Hinterland von Ephesos: Archäologisch-topographische Forschungen im Kaystros-Tal, ÖJh Ergänzungshefte 12 , Wien.

2018 Hermus (Gediz) Valley in Western Turkey. Results of an Archaeological Survey, Publications of Ancient Smyrna Excavations 11, Istanbul.

Meriç, R. and Öz, A.

2015 Bademgediği Tepe (Puranda) Near Metropolis, 609626, in: STAmpolidis et al. (eds.) 2015.

Meriç, R. and Mountjoy, P.A.

2002 Mycenaean Pottery from Bademgediği Tepe (Puranda) in Ionia: A preliminary report, IstMitt 52, 79-98.

Momigliano, N.

2009 Minoans at Iasos?, 121-140, in: C.F. Macdonald, E. Hallager and W.-D. Niemeier (eds.), The Minoans in the central, eastern and northern Aegean - New evidence. Acts of a Minoan Seminar 22-23 January 2005 in collaboration with the Danish Institute at Athens and the German Archaeological Institute at Athens. Monographs of the Danish Institute at Athens 8, Athens.

2012 Bronze Age Carian Iasos: Structures and Finds from the Area of the Roman Agora (c. 3000-1500 BC), Missione Archeologica Italiana di Iasos 4, Archaeologica 166, Roma.

MountJoy, P. A.

1998 The East Aegean - West Anatolian Interface in the Late Bronze Age: Mycenaeans and the Kingdom of Ahhiyawa, AnatSt 48, 33-68.

1999 Regional Mycenaean Decorated Pottery, Rahden.

Mouton, A., Rutherford, I. and Yakubovich, I. (eds.)

2013 Luwian Identities: Culture, Language and Religion Between Anatolia and the Aegean, Culture and History of the Ancient Near East 64, Leiden and Boston.

NieMEIER, W.-D.

2007a Westkleinasien und Ägäis von den Anfängen bis zur Ionischen Wanderung: Topographie, Geschichte und Beziehungen nach dem archäologischen Befund und den hethitischen Quellen, 37-96, in: Совет et al. (eds.) 2007. 2007b Milet von den Anfangen menschlicher Besiedlung bis zur Ionischen Wanderung, 3-20, in: COBET et al. (eds.) 2007.

Nosch And Laffineur (eds.)

2012 KOSMOS: Jewellery, Adornment and Textiles in the Aegean Bronze Age. Proceedings of the 13th International Aegean Conference, University of Copenhagen, Danish National Research Foundation's Centre for Textile Research, 21-26 April 2010. Aegaeum 33, Leuven and Liège

ÖZDOĞAN, M.

19911989 yılı Marmara bölgesi araştırmaları ve Toptepe kazısı, Kazı Sonucları Toplantısı 12 (1), 345-375.

1993 The Second Millennium of the Marmara Region, IstMitt 43, 151-164.

Parkinson, W.A. and Galaty. M.L.

2007 Secondary States in Perspective: An Integrated Approach to State Formation in the Prehistoric Aegean, American Anthropologist 109 (1), 113-129.

PAvÚK, P.

2008 “Grey Wares as a Phenomenon.” 12 Jun. 2008, in: B. Horejs and P. PAvúk (eds.): Aegean and Balkan Prehistory. http://www.aegeobalkanprehistory.net/index. php? $\mathrm{p}=$ article\&id_art $=5$ (6 Jul. 2018).

2014 Troia VI Früh und Mitte. Keramik, Stratigraphie und Chronologie, Studia Troica Monographien 3, Bonn.

2015 Between the Aegean and the Hittites: The Western Anatolia in Second Millennium BC, in: Stampolidis et al. (eds.) 2015, 81-114.

PAvúk, P. and Horejs, B.

2012 Mittel- und Spätbronzezeitliche Keramik Griechenlands. Sammlung Fritz Schachermeyr 3, Österreichische Akademie der Wissenschaften PhilosophischHistorische Klasse Denkschriften 439, Veröffentlichungen der mykenischen Kommission 31, Wien.

PAvúk, P. and Schubert, C.

2014 Die Troas in der Mittel- und Spätbronzezeit, 864-923, in: E. Pernicka, C. B. Rose and P. Jablonka (eds.): Troia 1988-2008: Grabungen und Forschungen. I. Forschungsgeschichte, Methoden und Landschaft, Studia Troica Monographien 5, Bonn.

Perrot, G. and Chipiez, Ch.

1984 Histoire de l'art dans l'antiquité. La Grèce Primitive, L'art Mycenien 6, Paris.

Philaniotou, O.

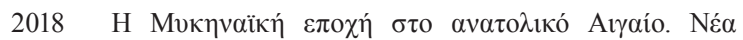

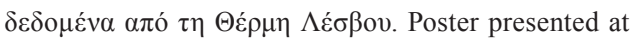
the 3rd International Interdisciplinary Colloquium The Periphery Of The Mycenaean World Recent Discoveries And Research Results in Lamia, 18-20 of May 2018. 
Pienią̇̇ek and PAvúk

2016 Towards understanding the socio-political structures and social inequalities in western Anatolia during the Late Bronze Age, 531-553, in: H. Meller, H.P. Hahn, R. Jung and R. Risch (eds.), Arm und reich. Zur Ressourcenverteilung in prähistorischen Gesellschaften. 8. Mitteldeutscher Archäologentag vom 22. bis 24. Oktober 2015 in Halle (Saale), Tagungen des Landesmuseums für Vorgeschichte Halle 14, Halle (Saale).

Pirson, F. and Zimmermann, M.

2014 The Hinterland of Pergamon: Economic Resources, Rural Settlements and Political Manifestation, 144161, in: F. Pirson and Scholl, A. (eds.) Pergamon: A hellenistic capital in Anatolia, Istanbul.

RADT, W.

1992 Die frühesten Wehrmauern von Pergamon und die zugehörigen Keramikfunde, Istanbuler Mitteilungen $42,163-234$.

RAmage, A.

1994 Early Iron Age Sardis and its neighbours, 163-172, in: A. ÇıLıngiroĞLu and D.H. French (eds.), Anatolian Iron Ages 3: The Proceedings of the Third Anatolian Iron Ages Colloquium held at Van, 6-12 August 1990, British Institute of Archaeology at Ankara Monograph 16. London.

Raymond, A., Kaiser, I., Rizzotto, L.-C. and Zurbach, J.

2016 Discerning Acculturation at Miletus: Minoanisation and Mycenaeanisation, 58-74, in: E. Gorogianni, P. PavúK and L. Girella (eds.), Beyond Thalassocracies: Understanding Processes of Minoanisation and Mycenaeanisation in the Aegean, Oxford and Philadelphia.

Roosevelt, C.H.

2010 Lydia before the Lydians, 37-73, in: CAHILL, N.D. (ed.), The Lydians and Their World. Catalogue of an Exhibit at the Yapı Kredi Vedat Nedim Tör Museum, İstanbul. İstanbul.

Roosevelt, C.H. and Luke, C.

2010 Central Lydia Archaeological Survey: 2008 Results, Araştırma Sonucları Toplantısı 27(2), 1-24.

2011 Central Lydia Archaeological Survey: 2009 Results, Araştırma Sonucları Toplantısı 28(2), 55-74.

2013 The Central Lydia Archaeological Survey: 2011 work at Kaymakçı and in the Marmara Lake basin. Araştırma Sonuçları Toplantısı 30 (1), 237-254.

2017 The story of a forgotten kingdom? Survey archaeology and the historical geography of central western Anatolia in the Late Bronze Age. Journal of European Archaeology 20 (1), 120-147.
Roosevelt, C. H., Luke, C., CobB, P., O’Grady,C. and B. SekeDAT, B.

2014 The Central Lydia Archaeological Survey, 2012 work at Kaymakçı and in the Marmara Lake basin, Araştırma Sonuçları Toplantısı 31 (1), 333-355.

Roosevelt, C. H., Luke, Ch., Ünlüsoy, S., Çakirlar, C., Marston, J.M., O〉Grady, C.R., Pavúk, P., Pieniążek, M., Mokrišoví, J., Scott, C., Shin, N. and Slim, F.

2018 Exploring Space, Economy, and Interregional Interaction at a Second-Millennium B.C.E. Citadel in Central Western Anatolia: 2014-2017 Research at Kaymakçı. American Journal of Archaeology 122 (4), 645-688.

Rose, C.B., Tеккок, B., Korpe, R. et al.

2007 Granicus River Valley Survey Project, 2004-2005, Studia Troica 17, 65-150.

SARI, D.

2013 The Cultural Development of Western Anatolia in the Third and Second Millennia BC and its Relationship with Migration Theories, 305-327, in: A. Mouton, I. RUTHERFord and I. YAKUBOvich (ed.), Luwian Identities: Culture, Language and Religion between Anatolia and the Aegean. Culture and History of the Ancient Near East 64. Leiden-Boston.

SAZCI, G.

2013 Maydos Kilisetepe Höyüğü: eine bronzezeitliche Hafensiedlung an den Dardanellen. Archäologisches Korrespondenzblatt 43(1), 29-40.

2016 Maydos Kilisetepe Höyüğü Kazısı 2014 Sezonu Çalışmaları. Kazı Sonuçları Toplantısı 37 (1), 539550 .

Sazci, G. and Başaran Mutlu, M.

2017 Maydos Kilisetepe Höyüğü Kazısı 2015 Sezonu Çalışmaları. Kazı Sonuçları Toplantısı 38 (1), 329342.

2018 Maydos-Kilisetepe: A Bronze Age Settlement on the Border Between Asía and Europe, 139-158, in: Gimatzidis et al. (eds.) 2018.

SCHACHNER, A.

1994/95 Untersuchungen zur chronologischen Stellung der grau-minyschen Keramik in Westanatolien unter Berücksichtigung der Schliemann-Sammlung im Berliner Museum für Vor- und Frühgeschichte, Acta praehistorica et archaeologica 26/27, 90-115.

Forthcoming Die Keramik der späteren Frühbronzezeit und des 2. Jts. v. Chr., in: M. ÖzdoĞAn, S. Kılıc and A. Schachner (eds.), Das südliche Marmaragebiet, Berlin.

Schachner, A. (ed.)

2017 Innovation versus Beharrung: Was macht den Unterschied des hethitischen Reichs im Anatolien des 2. Jahrtausends v. Chr.? Internationaler Workshop zu Ehren von Jürgen Seeher, Istanbul, 23-24. Mai 2014, BYZAS 23, İstanbul. 
Schachner, A. and Meric, $R$.

2000 Ein Stempelsiegel des späten 2. Jahrtausends v. Chr. aus Metropolis in Ionien, SMEA 42(1), 85-102.

Schlöffel, M., Schneider, St., Horejs, B., Meyer, C., Schütt, B. and Schwall, $\mathrm{CH}$.

2017 Ergebnisse der Arbeiten am Yeni Yeldeğirmentepe. Geoarchäologische Forschungen zur Bronzezeit im Bakırçaytal, Westtürkei, Poster presentedat the 13. Annual Meeting of the AG Geoarchäologie, 12.14. Mai 2017, Erlangen.

SCHNEIDER, S. et al. 2017

Schneider, S., M. Schlöffel, M., Schwall, Ch., Horejs, B. and SснÜтT, B.

2017 First stratigraphic evidence and absolute dating of a Bronze Age settlement in the Bakırçay valley in western Turkey, Journal of Archaeological Science: Reports 12, 2017, 316-322. doi:10.1016/j.jasrep.2017.02.011

SEEHER, J.

2005 Überlegungen zur Beziehung zwischen dem hethitischen Kernreich und der Westküste Anatoliens im 2. Jahrtausend v. Chr, 33-44, in: B. Horess, R. Jung, E. KAISER and B. TeržAn (eds.), Interpretationsraum Bronzezeit. Bernhard Hänsel von seinen Schülern gewidmet, Universitätsforschungen zur Prähistorischen Archäologie 121, Bonn.

Seeliger, M., Schneider,S., Brückner, H., Schütt, B., Feuser, S., Horejs, B., Zimmermann, M. and Pirson, F.

2011 Studying Pergamon's Environs - Geoarchaeological Research in Elaia and Baktrcay Valley, 48-65, in: E. Önen, M. Mutluer and N. Çetin (eds.), Proceedings of the International Bergama Symposium, 7-9 April 2011, Bergama.

SPIER, J.

1983 Prehistoric and Protohistoric Periods, 17-25, in: G. M. A. Hanfmann and W.E. Mierse (eds.), Sardis from Prehistoric to Roman Times. Results of the Archaeological Exploration of Sardis, 1958-1975, Cambridge, MA and London.

Stampolidis et al. (eds.)

Stampolidis, N., Maner, C. and Kopanias, K. (eds.)

2015 Nostoi: Indigenous Culture, Migration and Integration in the Aegean Islands and Western Anatolia during the Late Bronze and Early Iron Ages, Archaeology 58 , Istanbul.
ŞAHOĞLU, V.

2007 Çeşme-Bağlararası: A New Excavation in Western Anatolia, 309-322, in: F. Felten, W. Gauss and R. Smetana (eds.), Middle Helladic Pottery and Synchronisms. Proceedings of the International Workshop held at Salzburg, October 31st - November 2nd, 2004, Wien.

2015 Çeşme-Bağlararası: A Western Anatolian Harbour Settlement at the Beginning of the Late Bronze Age, 593-608, in: Stampolidis et al. (eds.) 2015.

Thumm-DoĞrayan, D., Pavúk, P. and Pienią̇̇ek, M.

in press Economy and storage strategies at Troy, in: D. GARcia, R. Orgeolet, M. Pomadère and J. Zurbach (eds.), Country in the city. Forms and functions of agro-pastoral activities in Mediterranean pre-Classical cities (Aegean and Western Mediterranean Protohistory). Conference held in Marseilles, 16-17. October 2014, Oxford.

VAESSEN, R

2016 Cosmopolitanism, communality and the appropriation of Myceanean pottery in western Anatolia, AnatSt 66, 43-65.

2017 Western Anatolia and the Aegean during the Late Bronze Age: A view from the Gulf of Izmir, 67-78, in: K. Żebrowska, A.Ulanowska and K. Lewartowski (eds.), Sympozjum Egejskie, Aegean Archaeology 1, Warsaw.

Votruba, S.

2015 Liman Tepe during the Late Bronze Age, 647-670, in: StAmpolidis et al. (eds.) 2015.

Weeden, M. and Ullmann, L.Z. (eds.)

2017 Hittite landscape and geography. Handbook of Oriental studies. Section 1, The Near and Middle East 121, Leiden and Boston.

ZuRBACH, J.

2015 Zur Rolle der kleinasiatischen Beziehungen in der mykenischen Palastwirtschaft, 407-418, in: D. PANAGIOTOPOUlos, I. Kaiser and O. KouKa (eds.), Ein Minoer im Exil. Festschrift für Wolf-Dietrich Niemeier, Universitätsforschungen zur prähistorischen Archäologie 270 , Bonn. 
